\title{
Modification by lateral mixing of the Warm Deep Water entering the Weddell Sea in the Maud Rise region
}

\author{
Harry Leach • Volker Strass • Boris Cisewski
}

Received: 8 July 2009 / Accepted: 21 September 2010

(C) Springer-Verlag 2010

\begin{abstract}
Deep water originating in the North Atlantic is transported across the Antarctic Circumpolar Current by eddies and, after circumnavigating of the Antarctic, enters the Weddell Gyre south of Africa. As it does so, it rises up from mid-depth towards the surface. The separate temperature and salinity maxima, the Upper and Lower Circumpolar Deep Waters, converge to form the Warm Deep Water. Cores of this water mass on the southern flank of the eastern Weddell Gyre show a change in characteristic as they flow westward in the Lazarev Sea. Observations have been made along four meridional sections at $3^{\circ} \mathrm{E}, 0^{\circ}, 3^{\circ} \mathrm{W}$ and $6^{\circ} \mathrm{W}$ between 60 and $70^{\circ} \mathrm{S}$ during the Polarstern Cruise ANTXXIII/2 in 2005/2006. These show that a heterogeneous series of warm and salty cores entering the region from the east both north and south of Maud Rise $\left(65^{\circ} \mathrm{S}, 3^{\circ} \mathrm{W}\right)$ gradually merge and become more homogeneous towards the west. The gradual reduction in the variance of potential temperature on isopycnals is indicative of isopycnic mixing processes. A multiple
\end{abstract}

Responsible Editor: Karen J. Heywood

H. Leach $(\bowtie)$

Department of Earth and Ocean Sciences,

University of Liverpool,

4 Brownlow Street,

Liverpool L69 3GP, UK

e-mail: leach@liv.ac.uk

V. Strass $\cdot$ B. Cisewski

Alfred-Wegener-Institut für Polar- und Meeresforschung,

Postfach 1201 61,

27515 Bremerhaven, Germany

B. Cisewski

Institut für Umweltphysik, Universität Bremen,

Postfach 3304 40,

28334 Bremerhaven, Germany regression technique allows diagnosis of the eddy diffusivities and, thus, the relative importance of isopycnic and diapycnic mixing. The method shows that the isopycnic diffusivity lies in the range $70-140 \mathrm{~m}^{2} \mathrm{~s}^{-1}$ and the diapycnic diffusivity reaches about $3 \times 10^{-6} \mathrm{~m}^{2} \mathrm{~s}^{-1}$. Scale analysis suggests that isopycnic diffusion dominates over diapycnic diffusion in the erosion of the Warm Deep Water cores.

Keywords Weddell Gyre $\cdot$ Lazarev Sea $\cdot$ Maud Rise $\cdot$ Warm Deep Water $\cdot$ Mixing

\section{Introduction}

The deepest limb of the global overturning circulation is driven by the formation of dense water around the Antarctic continent and in the Weddell Sea in particular. A major source of water mass for the dense Antarctic Bottom Water, which spreads in the deepest channels and basins as far north as $50^{\circ} \mathrm{N}$ in the Atlantic (e.g. Lynn and Reid 1968), is - as suggested long ago by Brennecke (1921), Deacon (1933) and Mosby (1934) - the so-called Warm Deep Water (WDW). This Deep Water, originally formed in the northern North Atlantic, makes its way via the Deep Western Boundary Current to the Southern Ocean where it joins the Circumpolar Current. It circles the Antarctic and becomes the Circumpolar Deep Water, and eventually, somewhere south of Africa, some of this Water becomes entrained in the Weddell Gyre, where it is called the Warm Deep Water (Carmack 1974), conspicuous by its temperature and salinity maximum. Here, it rises up to a few hundred metres below the surface, loses heat to the surface mixed layer and further to the atmosphere (Bagriantsev et al. 1989), interacts with the ice shelf (e.g. Seabrooke et al. 
1971) by mixing with the High Salinity Shelf Water, formed by brine rejection during sea ice formation, and Ice Shelf Water, cooled by contact with the ice shelf (Gill 1973). Eventually, after the various water mass transformation processes and loss of buoyancy, part of the WDW becomes the newly formed Weddell Sea Deep or Bottom Water. Below the WDW core, both the temperature and salinity decrease to the bottom. The Weddell Sea Deep Water (WSDW) has a potential temperature range of $0.0^{\circ} \mathrm{C}$ to $-0.7^{\circ} \mathrm{C}$ and the Weddell Sea Bottom Water (WSBW) potential temperatures below $-0.7^{\circ} \mathrm{C}$. Within the Gyre itself, this distinction is rather arbitrary, but is important for distinguishing water which can escape through passages in the South Scotia Ridge to eventually fill the ocean abyss as Antarctic Bottom Water. A recent modelling study (Iudicone et al. 2008) suggests that about $40 \%$ of the North Atlantic Deep Water is upwelled in the Southern Ocean, and of this, $40 \%$ is transformed into Antarctic Bottom Water.

The fact that a large portion of this densest water mass of the world ocean is formed in the Weddell Sea is related to its geographical setting and the climatic mean wind field which drives a basin-scale cyclonic circulation, the Weddell Gyre. The Weddell Gyre is limited to the south by the Antarctic continent, to the west by the Antarctic Peninsula, to the north by the Antarctic Circumpolar Current and closes to the east in a less well-defined way between 10 and $40^{\circ}$ E (Deacon 1979; Orsi et al. 1993; Schröder and Fahrbach 1999). In this way, the Weddell Gyre maintains a transport of relatively warm water masses southward into regions where water mass transformation is most intense and also a subsequent transport of the modified water masses back to the north.

Whilst the traditional view is that the main inflow into our working region, the south central part of the Weddell Gyre, is north of Maud Rise (Gordon et al. 1978; Deacon 1979; Orsi et al. 1993; Beckmann et al. 1999), the Greenwich Meridian sections sometimes show higher temperatures and salinities south of the latitude of Maud Rise. However, this does not necessarily mean that this water is entering south of Maud Rise at $65^{\circ} \mathrm{S}, 3^{\circ} \mathrm{E}$, but may just be time-dependent eddies which seem to develop in the flow in the lee of the Rise. The character of the WDW is known to vary in time, and there has been some debate about the causes of this (Fahrbach et al. 2004, 2006; Smedsrud 2005, 2006).

Generally, a fourfold layering in terms of water masses within the Weddell Gyre is recognised (Carmack 1974; Orsi et al. 1993); however, not all authors use the same nomenclature. At the top, there is a cold and fresh surface layer of variable properties depending on place and season, influenced by local warming and cooling and sea ice formation and melting. Beneath the surface layer is the warmest and saltiest water with maximum temperature and salinity at a few hundred metres depth. This is either still known as the Circumpolar Deep Water (Orsi et al. 1993) or the WDW (Carmack 1974). On entry into the Gyre near $30^{\circ} \mathrm{E}$, this water has a temperature of about $1.5^{\circ} \mathrm{C}$ and salinity of about 34.74 , but after its passage around the Gyre, these have been reduced to about $0.4^{\circ} \mathrm{C}$ and 34.68 (Fahrbach et al. 1994). The eastern Weddell Gyre is a complex region where Circumpolar Deep Water mixes with colder and fresher WDW returning from the Weddell Sea to form a new WDW which enters the Gyre here (Gouretski and Danilov 1993; Schröder and Fahrbach 1999).

Our area of investigation includes the isolated topographic feature known as Maud Rise. This feature has aroused considerable interest in its influence on the regional oceanographic properties and their role in reducing the sea ice cover (e.g. Bersch et al. 1992; Muench et al. 2001; de Steur et al. 2007). In general, there is water trapped over the Rise in a Taylor column. In the thermocline, this water is colder and fresher than the surrounding water; in particular, the characteristic WDW core is missing, whilst in the otherwise colder and fresher surface layer, the presence of the rise may be indicated by water which is more saline and, in summer, warmer than the surrounding water. In contrast, in a halo-like feature around the Rise, the thermocline water seems conspicuously warm and salty (e.g. Muench et al. 2001). In particular, to the north is the principal inflow of WDW to the region. Enhanced mixing over the Rise by tides has been held responsible (Beckmann et al. 2001) for initiating the Weddell Polynya (Comiso and Gordon 1987), though this is disputed by others (Muench et al. 2001) who favour surface exchanges and processes driven by them. Sometimes isolated, well-mixed features attributed to deep convection are reported in the vicinity of the Rise (e.g. Gordon 1978), which probably can be traced back to eddies shed from the periphery of the Taylor column above the Rise (Holland 2001). Akimoto (2006) argues that convective overturning on the flanks of the rise creates a density front that is baroclinically unstable and thus a source of eddies.

In this paper, we consider the development of the $\theta \sigma_{\theta}$ character of the Warm Deep Water as it moves westwards across the longitude of Maud Rise and further downstream through the Lazarev Sea, just before it veers southwestwards to become the source water mass for the transformation processes that take place in the southern Weddell Sea. In particular, we interpret the changes in WDW characteristics as mixing and use the observed changes in $\theta \sigma_{\theta}$ variance to estimate bulk isopycnic and diapycnic diffusivities.

Many studies of the Maud Rise region, particularly those associated with the Antarctic Zone Flux Experiment (McPhee et al. 1996, 1999; McPhee 2000; Muench et al. 2001) have been concerned with the detail of exchange 
processes. In this paper, we do not set out to detract from that work but instead adopt a new approach by posing a different question: If, as is often the case in modelling large-scale ocean flows, we need to represent the observed decrease in potential temperature variance on isopycnic surfaces as time progresses by a diffusive process, how big should the isopycnic and diapycnic eddy diffusivities be?

Horizontal isopycnic mixing is generally thought to be dominated by eddies created by baroclinic instability and as such can reasonably be regarded as a continuous process, although individual eddies have their life cycles. Vertical diapycnic mixing on the other hand is not so much a continuous process and the eddy diffusivity at best represents the statistics of intermittent mixing events. Using eddy diffusivities is not therefore ideal, from the analytical point of view, but it gives us the opportunity to compare the rate of water mass modification here to that in other ocean regions.

\section{Observations}

\subsection{Data}

The data used in this study were collected during the Polarstern Cruise ANTXXIII/2 in austral summer 2005/ 2006 (Strass 2007). This cruise formed one of a series of four cruises dedicated to the Lazarev Sea Krill Study (LAKRIS) aimed at investigating the biology of Antarctic Krill in the Lazarev Sea and relating their life cycle to the circulation of the Weddell Gyre. The Lazarev Sea is named after Mikhail Petrovich Lazarev (1788-1851), a Russian naval officer who, together with Bellingshausen, explored this region and found the Antarctic Continent here on 16th January 1820 . It comprises deep abyssal plain, except for one topographic feature, namely Maud Rise, which rises to $1,098-\mathrm{m}$ depth at about $65^{\circ} 10^{\prime} \mathrm{S}, 2^{\circ} 30^{\prime} \mathrm{E}$.

Data were collected between 60 and $70^{\circ} \mathrm{S}$ along four sections with $3^{\circ}$ longitude spacing at $3^{\circ} \mathrm{E}, 0^{\circ}, 3^{\circ} \mathrm{W}$ and $6^{\circ} \mathrm{W}$ (Fig. 1). Stations were $0.5^{\circ}$ latitude apart and many, but not all, CTD casts were to full depth. The sections thus all cut the westward-flowing southern limb of Weddell Gyre in this region. The survey was started on 6th December 2005 at $70^{\circ} \mathrm{S}, 3^{\circ} \mathrm{E}$ in the SE corner of the survey area and finished on 2nd January 2006 at $70^{\circ} \mathrm{S}, 6^{\circ} \mathrm{W}$ in the SW corner; the sections were worked systematically from east to west. In addition to the hydrographic measurements, the ship was fitted with a vessel-mounted acoustic Doppler current profiler (VM-ADCP), the data from which have been used to estimate the flow speed in the area. Though the station spacing is marginal for resolving the detail of mesoscale features, it seems unlikely that the systematic reduction in isopycnic temperature variance observed - see

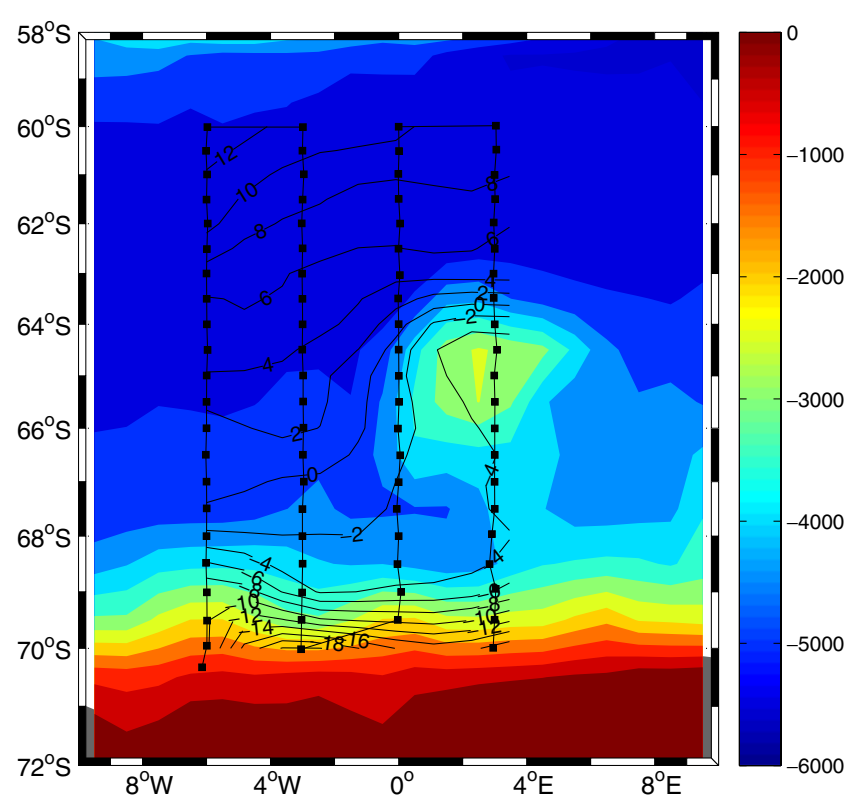

Fig. 1 Cruise track showing sections along $3^{\circ} \mathrm{E}, 0^{\circ}, 3^{\circ} \mathrm{W}$ and $6^{\circ} \mathrm{W}$. The bathymetry is shown in colour with a scale in metres; Maud Rise is centred near $65^{\circ} \mathrm{S}, 3^{\circ} \mathrm{E}$. Superimposed is the stream function based on VM-ADCP data from the layer $100-150 \mathrm{~m}$. The contour interval is $2 \times 10^{3} \mathrm{~m}^{2} \mathrm{~s}^{-1}$, which corresponds to approximately 2-cm dynamic height. The flow is generally westward. Notice how the topographically controlled flow in the east fans out to form a broader flow in the west

below — is due to accidentally hitting the extreme values in the east and missing them in the west.

\subsection{Current measurements}

The ship's VM-ADCP was an RDI $150-\mathrm{kHz}$ Ocean Surveyor. The stream function based on the data from this instrument for the layer $100-150 \mathrm{~m}$ is shown in Fig. 1. For this analysis, the VM-ADCP data averaged at the stations were used and corrected using the tidal model of Padman et al. (2002). At $3^{\circ} \mathrm{E}$ on the eastern boundary of our area, it shows two jets, one between 63 and $64^{\circ} \mathrm{S}$, on the northern flank of Maud Rise, and another between 69 and $70^{\circ} \mathrm{S}$, close to the continental shelf. The northern jet curves around Maud Rise and then coalesces with the southern jet so that at $6^{\circ} \mathrm{W}$, on the western boundary of our area, there is just one broader flow. The flow speed within the jets north of Maud Rise and near the southern boundary correspond in this analysis to about $8 \mathrm{cms}^{-1}$.

The mean zonal flow across each of the four sections from the VM-ADCP data for the layer 21-249 $\mathrm{m}$ is shown in Table 1. For this, the high-resolution, every $5 \mathrm{~km}, \mathrm{VM}-$ ADCP data were used; these were also corrected using the Padman et al. (2002) model. The flow has a magnitude of between 2 and $3 \mathrm{cms}^{-1}$ westward with confidence limits of about $0.1 \mathrm{cms}^{-1}$ based on the statistics of each section 
Table 1 Mean zonal flow across sections from ship's VM-ADCP data for the layer $21-249 \mathrm{~m}$

\begin{tabular}{llc}
\hline Longitude & Mean $u\left(\mathrm{cms}^{-1}\right)$ & Confidence limits $\left(\mathrm{cms}^{-1}\right)$ \\
\hline $3^{\circ} \mathrm{E}$ & -2.56 & 0.17 \\
$0^{\circ}$ & -1.90 & 0.10 \\
$3^{\circ} \mathrm{W}$ & -3.06 & 0.10 \\
$6^{\circ} \mathrm{W}$ & -2.08 & 0.06 \\
Mean & $-2.4 \pm 0.5$ & \\
\hline
\end{tabular}

separately. However, the differences in mean flow from one section to the next would represent significant divergence, and the differences are more likely to be due to temporal variability, incomplete tidal corrections or other sampling errors. Consequently, it was decided to average the values together, which gave an overall mean westward flow of $2.4 \pm 0.5 \mathrm{~cm} \mathrm{~s}^{-1}$. Based on this mean speed, the mean transit time in days for water from one section to the next is 68.0 days, assuming a mean spacing of $141 \mathrm{~km}$ between the sections.

The density surface $27.80 \mathrm{kgm}^{-3}$ has a mean depth of $227 \mathrm{~m}$ and is so still within the VM-ADCP depth range. The remaining deeper surfaces for which significant solutions for the mixing coefficients could be found were 27.81 and $27.82 \mathrm{kgm}^{-3}$, and these had average depths of 285 and $406 \mathrm{~m}$, respectively, just below the VM-ADCP range.

\subsection{Hydrography}

First, the details of each of the four sections moving systematically from east to west will be considered in turn (Figs. 2, 3, 4 and 5); for each section, the topography has been included in the figures as a small panel at the bottom. Because we are only concerned with the development of the WDW, we will only show the top $1,000 \mathrm{~m}$ of the water column. All sections show a cold and fresh surface layer with an underlying warm and salty Deep Water layer. This is the last remnant of the Deep Water, formed originally in the northern North Atlantic, which makes its way here via the ACC, becoming the Circumpolar Deep Water and eventually being entrained as WDW into the eastern end of the Weddell Gyre at about $30^{\circ}$ E. The temperature maximum is usually in the depth range $200-300 \mathrm{~m}$, whilst the salinity maximum is slightly deeper and covers a slightly broader depth range.

The $3^{\circ} \mathrm{E}$ temperature and salinity sections are shown in Fig. 2. When looking at this section, it should be remembered that it passes close to the summit of Maud Rise at about $64.5^{\circ} \mathrm{S}$ latitude, though along this section the water is not shallower than $2,000 \mathrm{~m}$. The sections show two Deep Water cores, one north of Maud Rise at $63.5^{\circ} \mathrm{S}$ and one near the continental slope at $68.5^{\circ} \mathrm{S}$. These have temperatures of $1.1^{\circ} \mathrm{C}$ and $0.9^{\circ} \mathrm{C}$, and salinities of 34.69 and 34.70, respectively. The $0^{\circ}$, Greenwich Meridian section (Fig. 3) shows two Warm Deep Water cores at $64^{\circ} \mathrm{S}$ and $67^{\circ} \mathrm{S}$, closer together than at $3^{\circ} \mathrm{E}$. The temperature maxima are about $1.1^{\circ} \mathrm{C}$ and $0.9^{\circ} \mathrm{C}$, and the salinity maxima both reach 34.70 , though the more northern core shows a greater extent of water at this salinity. The $3^{\circ} \mathrm{W}$ section (Fig. 4) shows a number of cores of Warm Deep Water with temperature maxima of $0.9^{\circ} \mathrm{C}$ at $62^{\circ} \mathrm{S}, 1.0^{\circ} \mathrm{C}$ at $65^{\circ} \mathrm{S}, 0.9^{\circ} \mathrm{C}$ at $66.5^{\circ} \mathrm{S}$ and $0.8^{\circ} \mathrm{C}$ at $67.5^{\circ}$ $69^{\circ} \mathrm{S}$. The salinity reaches 34.70 in three of these cores, at 62,65 and $66.5^{\circ} \mathrm{S}$. At $6^{\circ} \mathrm{W}$ (Fig. 5), the core seems to be in the south with a small temperature maximum of $0.9^{\circ} \mathrm{C}$ at $65^{\circ} \mathrm{S}$ and a broad area above $0.8^{\circ} \mathrm{C}$ stretching as far as $68^{\circ} \mathrm{S}$. The salinity shows a broad maximum above 34.69 covering much of the section from 62 to $68.5^{\circ} \mathrm{S}$. Such changes, a decrease in peak temperatures and salinities and a broadening of the warm and salty core in the direction of the mean flow, would be expected to occur under the action of mixing.

The potential temperature, $\theta$, on potential density, $\sigma_{\theta}$, surfaces for the four sections are shown in Fig. 6; the profiles are colour-coded by latitude. All show the cold surface water at the top above the warmer potential temperature maximum of the Warm Deep Water at intermediate depth between the isopycnals 27.78 and $27.82 \mathrm{~kg} \mathrm{~m}^{-3}$ falling to the colder WSDW/WSBW below. The general impression moving from east to west is of a reduction in the variability of $\theta$ on $\sigma_{\theta}$ surfaces, both above but more importantly within the Deep Water core. The $6^{\circ} \mathrm{W}$ section (Fig. 6d) in particular shows profiles which are much more clustered together. It is this reduction of variability of $\theta$ which suggests particularly the possibility of isopycnic mixing; diapycnic mixing would reduce the potential temperature maximum for each profile independently, but not the overall variability so much as each profile would be mixing on its own. The impression obtained from these diagrams can be quantified by plotting the standard deviation of potential temperature on potential density surfaces for each of the four sections, and this is presented in Fig. 7. Now the reduction in standard deviation from section to section is quite clear with maxima of about $0.82,0.48,0.34$ and $0.24 \mathrm{~K}$ for each of the sections from east to west, respectively.

In order to test whether or not the observed changes in the structure of the potential temperature distribution were due to the reorganisation of the water within the thermocline or due to heat exchanges with the surroundings, the heat content of the layer $150-1,000 \mathrm{~m}$ was calculated for each of the four sections for the latitude range $60-69^{\circ} \mathrm{S}$ (using a reference temperature of $-2^{\circ} \mathrm{C}$ ). Reorganisation could include horizontal or vertical mixing processes. Heat 
Fig. 2 a The $3^{\circ}$ E section potential temperature: above $0^{\circ} \mathrm{C}$, the contour interval is $0.5 \mathrm{~K}$ and below $0.1 \mathrm{~K}$. The potential temperature maximum at $63.5^{\circ} \mathrm{S}$, north of Maud Rise, is $1.1^{\circ} \mathrm{C}$ and at $68.5^{\circ} \mathrm{S}$ is $0.9^{\circ} \mathrm{C}$. The colour scale is the potential temperature in degree Celsius. b Salinity: below 34.60 the contour interval is 0.10 and above 0.01 . The salinity maximum at $63.5^{\circ} \mathrm{S}$, north of Maud Rise, is 34.69 and at $68.5^{\circ} \mathrm{S}$ is 34.70 . The colour scale is the salinity. A small panel showing the bottom topography is included beneath each section

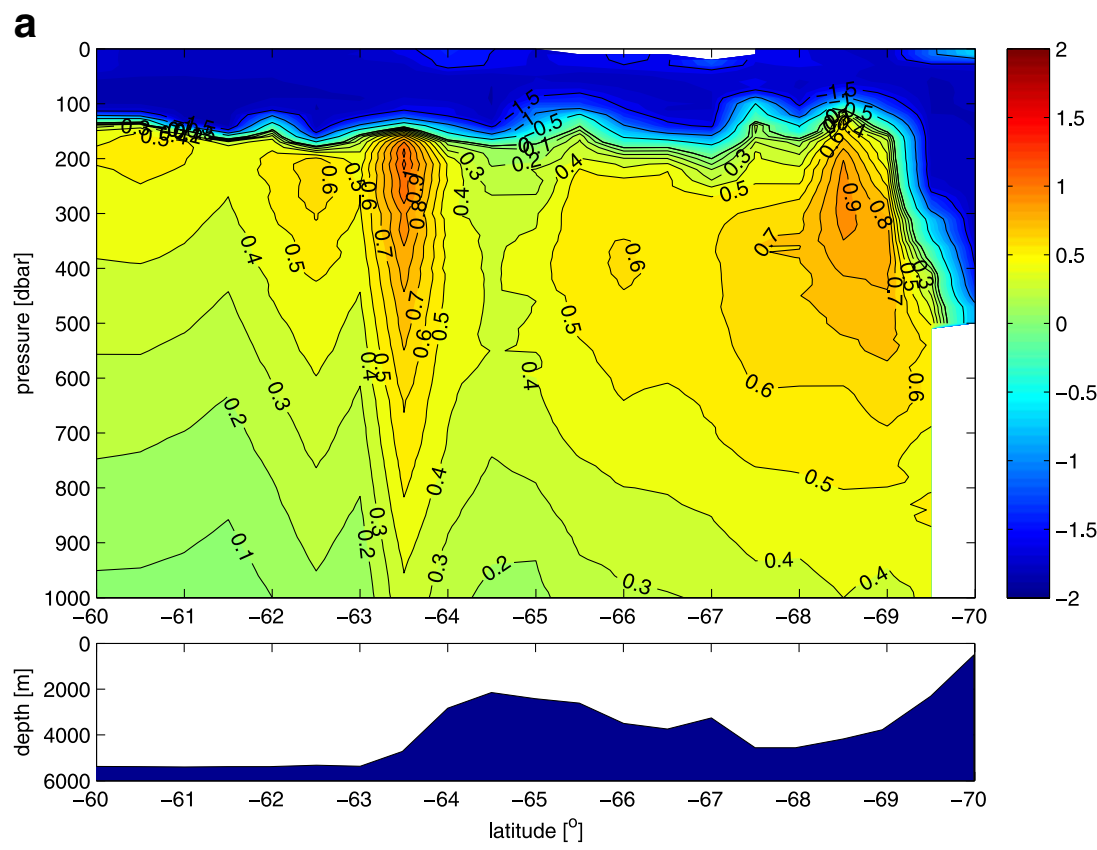

b

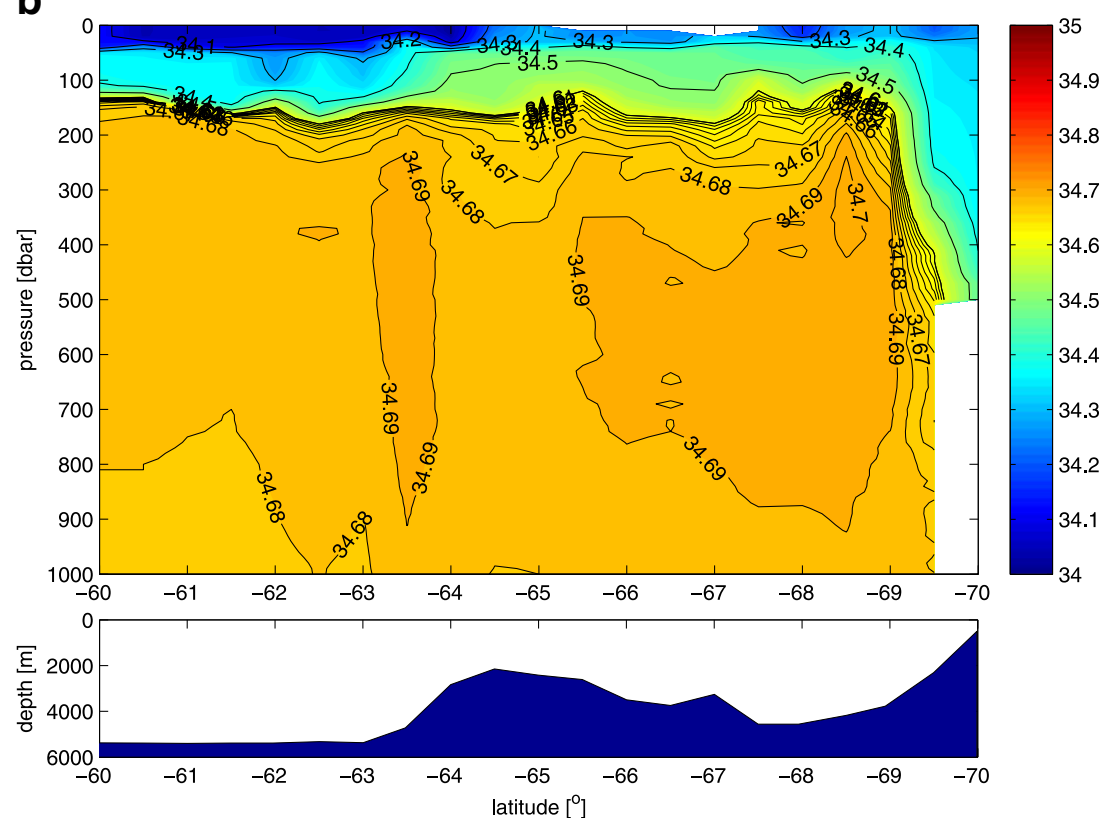

exchanges would largely be with the surface layer or ultimately the atmosphere, but could include exchanges at the lateral boundaries. The top of this layer was chosen as $150 \mathrm{~m}$ as the best compromise to exclude the surface seasonal layer but to include the Warm Deep Water core, though the depth of these features varies along the sections investigated (see Figs. 2, 3, 4 and 5). The $3^{\circ}$ E section passes sufficiently far away from the summit of Maud Rise that the water depth is never less than $2,000 \mathrm{~m}$, except close to the continent at the southern end of the section. This heat content is shown graphically in Fig. 8 and numerically in Table 2. The confidence limits are based on treating the individual stations as independent samples. The heat content changes from section to section appear to be within the confidence limits of the heat content, thus indicating that the changes cannot reliably be ascribed to exchanges with the surroundings. Interestingly, the total heat content change between the first and last sections appears to be virtually zero.

In Table 2, the heat content changes from section to section have, for comparison's sake, also been converted to equivalent average surface fluxes, using the mean transit time between sections of 68.0 days based on the VMADCP data, to changes in the mean temperature for the 
Fig. 3 a The $0^{\circ}$ section potential temperature: above $0^{\circ} \mathrm{C}$, the contour interval is $0.5 \mathrm{~K}$ and below $0.1 \mathrm{~K}$. The potential temperature maxima at 64 and $67^{\circ} \mathrm{S}$ are $1.1^{\circ} \mathrm{C}$ and $0.9^{\circ} \mathrm{C}$, respectively. The colour scale is the potential temperature in degree Celsius. b Salinity: below 34.60 , the contour interval is 0.10 and above 0.01 . The salinity maxima both reach 34.70 . The colour scale is the salinity. A small panel showing the bottom topography is included beneath each section
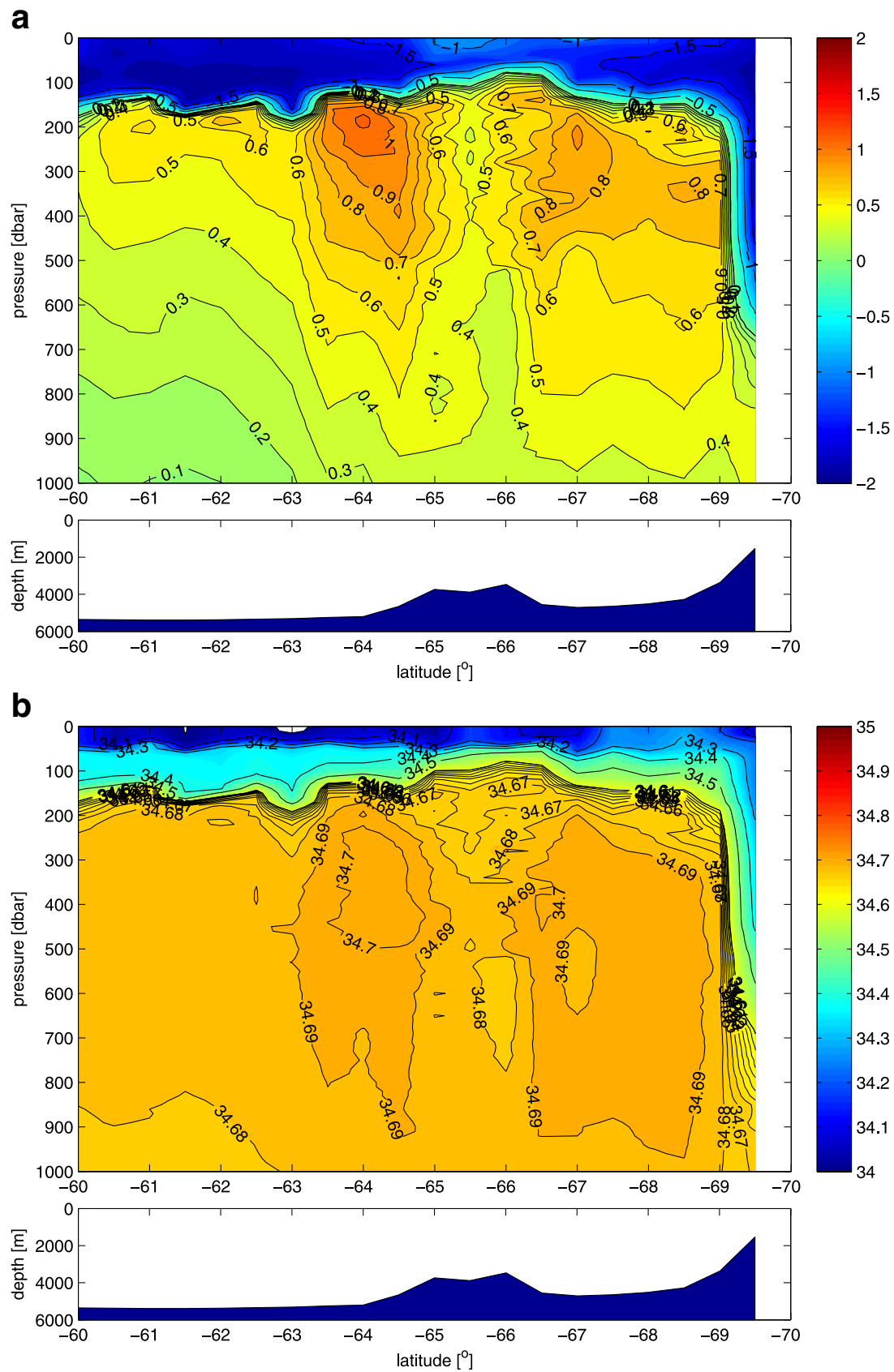

layer and to mean changes in depth of the surface layer, assuming a temperature contrast of $3 \mathrm{~K}$. The greatest heat content was observed at $0^{\circ}$, and a thinning of the surface layer can be seen here between about $64.5^{\circ} \mathrm{S}$ and $67^{\circ} \mathrm{S}$ and there are also more extensive areas of warmer water than in the $3^{\circ} \mathrm{E}$ section. Moving away towards the west, the heat content declines again. The equivalent average heat fluxes calculated are similar to the average values of $20-30 \mathrm{Wm}^{-2}$ reported from the ANZFLUX Experiment (McPhee et al. 1999; Muench et al. 2001). The calculations in Table 2 show that a modest deepening of the surface layer by 10 $15 \mathrm{~m}$ is sufficient to satisfy this requirement. The sections west of $0^{\circ}$ (Figs. 4 and 5) show no evidence of deep convection; on the contrary, the scar left by Maud Rise at $65.5^{\circ}$ and $66^{\circ} \mathrm{S}$ on the Greenwich Meridian (Fig. 3) has been healed by $3^{\circ} \mathrm{W}$.

\section{Calculations}

Between $3^{\circ} \mathrm{E}$ and $6^{\circ} \mathrm{W}$, the two westward flows-one north of Maud Rise and one to the south - fan out to form a broad westward flow; the Antarctic Coastal Current remains at the shelf edge. In addition, the water 
Fig. 4 a The $3^{\circ} \mathrm{W}$ section potential temperature: above $0^{\circ} \mathrm{C}$, the contour interval is $0.5 \mathrm{~K}$ and below $0.1 \mathrm{~K}$. There are cores of Deep Water with potential temperature maxima of $0.9^{\circ} \mathrm{C}$ at $62^{\circ} \mathrm{S}, 1.0^{\circ} \mathrm{C}$ at $65^{\circ} \mathrm{S}$, $0.9^{\circ} \mathrm{C}$ at $66.5^{\circ} \mathrm{S}$ and $0.8^{\circ} \mathrm{C}$ at $67.5-69^{\circ} \mathrm{S}$. The colour scale is the potential temperature in degree Celsius. b Salinity: below 34.60 , the contour interval is 0.10 and above 0.01 . The salinity reaches 34.70 in three cores, at 62, 65 and $66.5^{\circ} \mathrm{S}$. The colour scale is the salinity. A small panel showing the bottom topography is included beneath each section

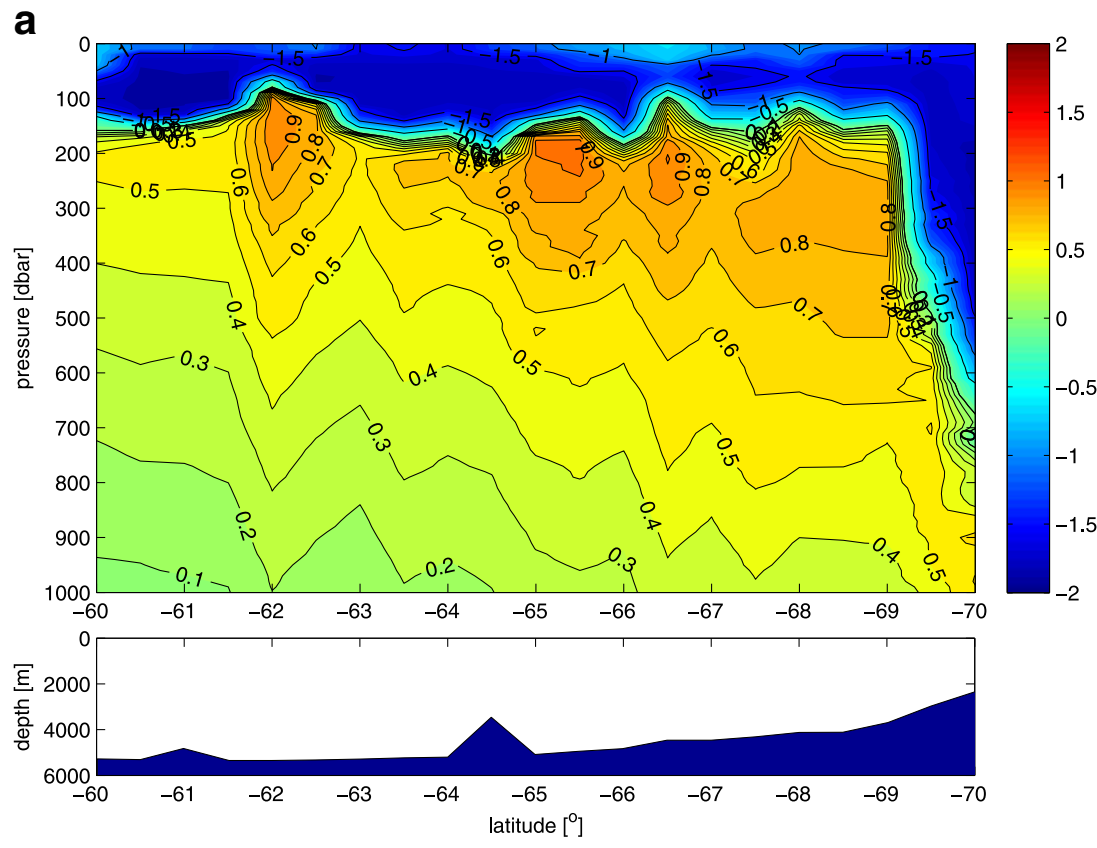

b

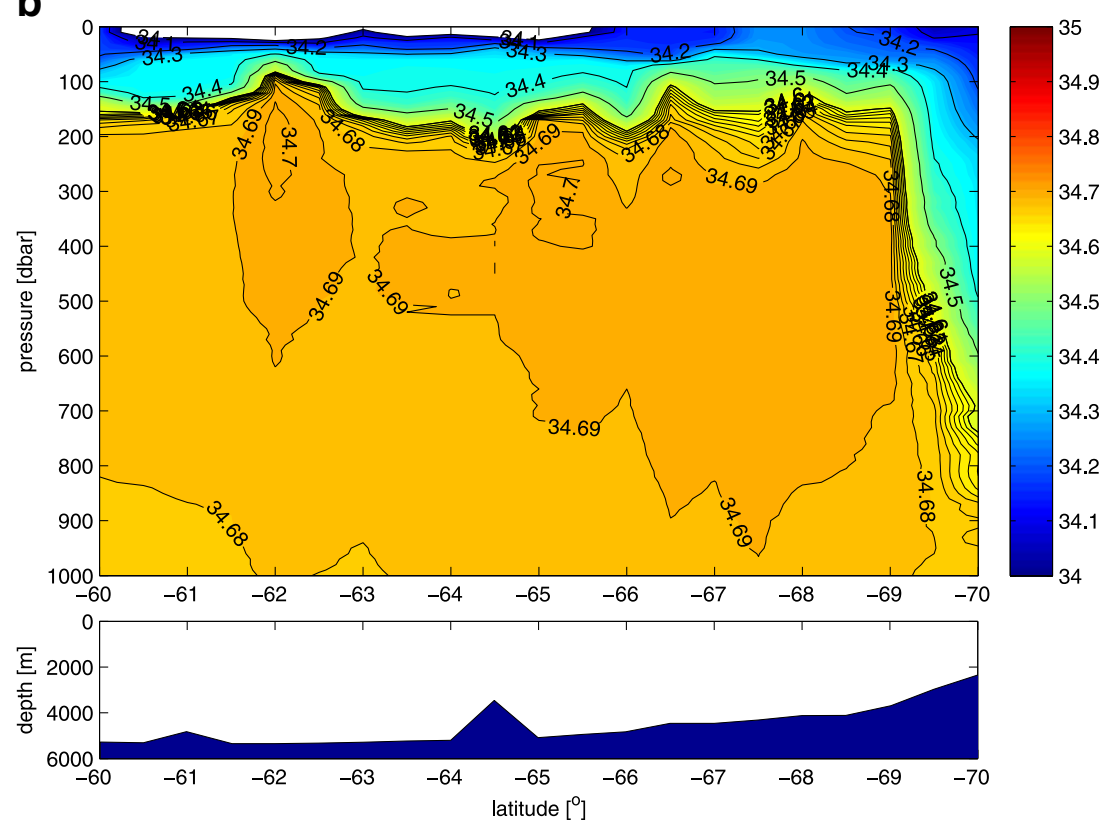

mass characteristics also converge with a reduction of isopycnic temperature variance. The peak values of temperature and salinity have reduced slightly moving across the region from east to west. In particular, the reduction of temperature variance on isopycnals suggests that isopycnic mixing is occurring; diapycnic mixing would not have the same ability to reduce this variance as it treats each water column independently of its neighbours and thus could not account for a transport of heat along isopycnals. From the changes observed, it is possible to learn something about the effectiveness of mixing in this region.

\subsection{Method}

In order to estimate the equivalent bulk eddy diffusivities for water below the seasonal layer, we assume that water flows west at an average speed measured using the VM-ADCP. Changes in potential temperature relative to this mean flow are ascribed to diffusive processes. This is effectively a heat budget equation; we assume that below the seasonal layer, there are no diabatic effects. Furthermore, all processes modifying the potential temperature distribution are parameterised as diffusion. In practice, processes within the pycnocline are more complicated than this and, for example, 
Fig. 5 a The $6^{\circ} \mathrm{W}$ section potential temperature: above $0^{\circ} \mathrm{C}$, the contour interval is $0.5 \mathrm{~K}$ and below $0.1 \mathrm{~K}$. The core is in the south with a small potential temperature maximum of $0.9^{\circ} \mathrm{C}$ at $65^{\circ} \mathrm{S}$ and a broad area above $0.8^{\circ} \mathrm{C}$ stretching as far as $68^{\circ} \mathrm{S}$. The colour scale is the potential temperature in degree Celsius. b Salinity: below 34.60 , the

contour interval is 0.10 and above 0.01 . The salinity shows a broad maximum above 34.69 covering much of the section from 62 to $68.5^{\circ} \mathrm{S}$. The colour scale is the salinity. A small panel showing the bottom topography is included beneath each section

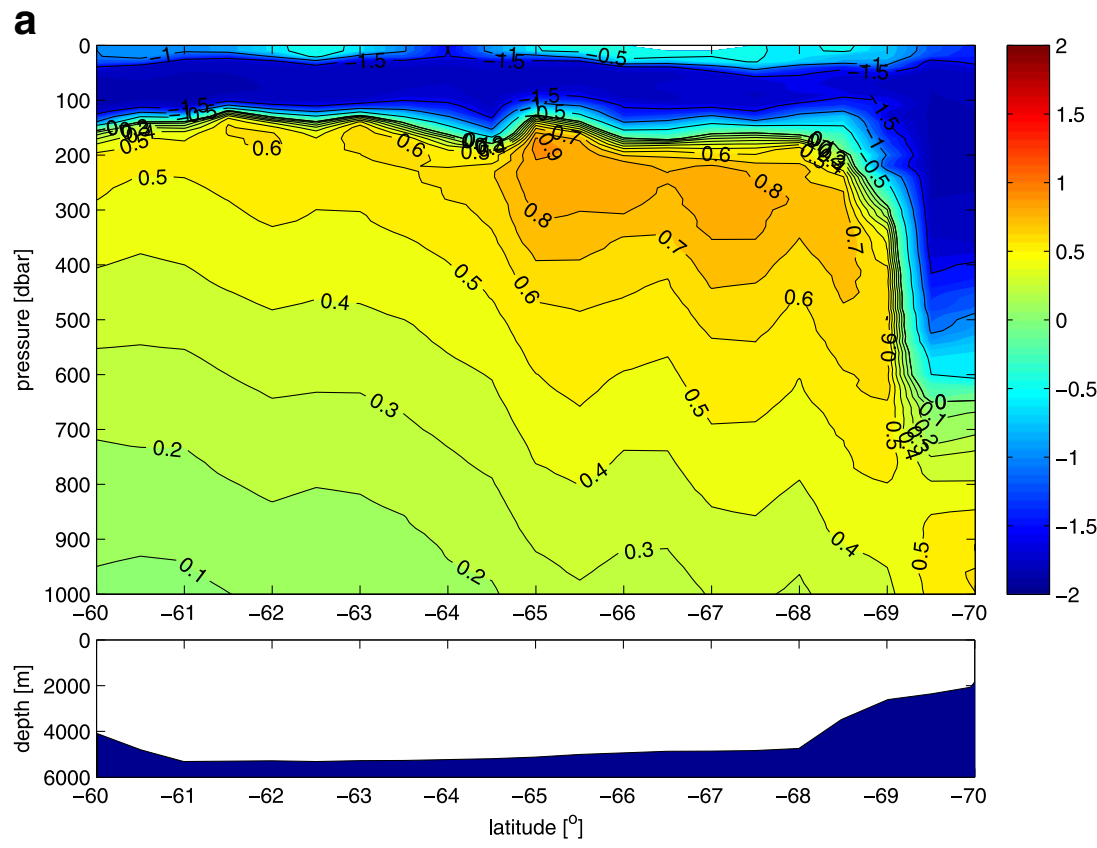

b

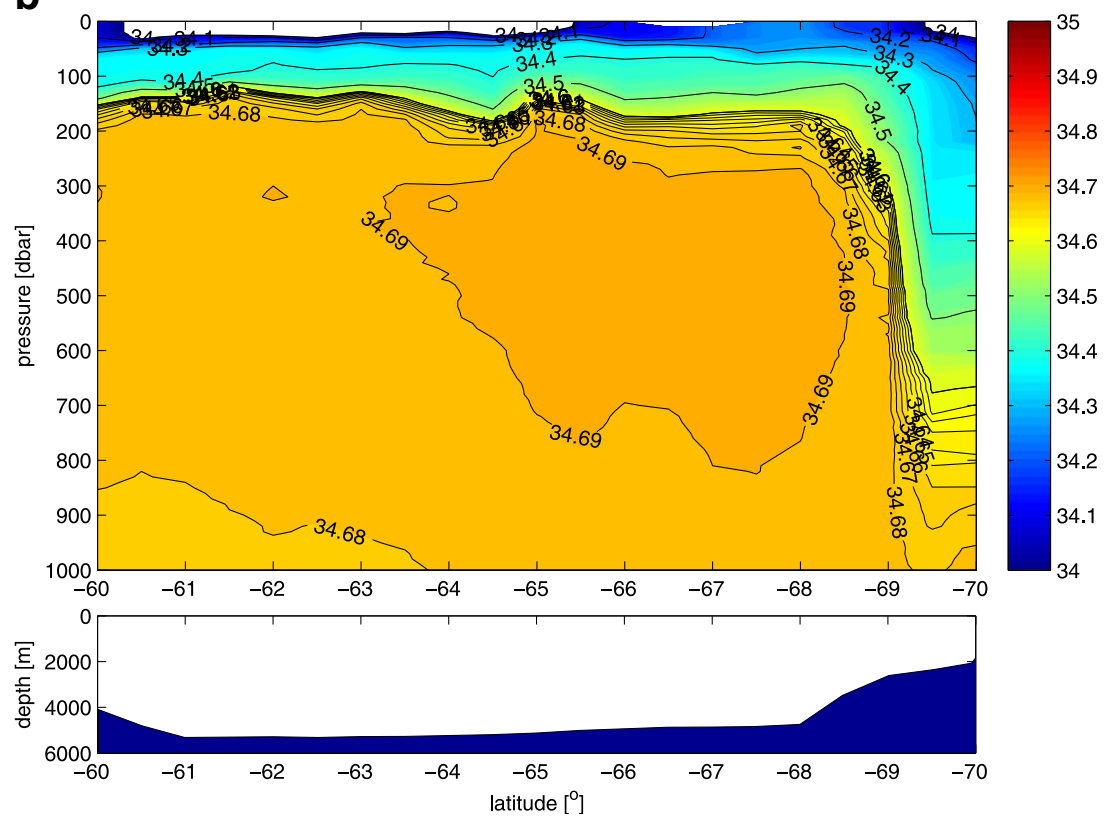

a vertical diffusion coefficient effectively stands for the frequency of intermittent mixing events. If the time rate of change of the potential temperature, $\theta$, of water parcels is balanced by horizontal and vertical (isopycnic and diapycnic) mixing in a Lagrangian heat budget, then a diffusion equation can be formulated:

$$
\begin{aligned}
\frac{\mathrm{d} \theta}{\mathrm{d} t}= & K_{h} \frac{1}{2}\left(\left.\frac{\partial^{2} \theta}{\partial y^{2}}\right|_{\text {initial }}+\left.\frac{\partial^{2} \theta}{\partial y^{2}}\right|_{\text {final }}\right) \\
& +K_{v} \frac{1}{2}\left(\left.\frac{\partial^{2} \theta}{\partial z^{2}}\right|_{\text {initial }}+\left.\frac{\partial^{2} \theta}{\partial z^{2}}\right|_{\text {final }}\right)
\end{aligned}
$$

where the symbols have their usual meanings, $K_{\mathrm{h}}$ and $K_{\mathrm{v}}$ are the isopycnic and diapycnic eddy diffusivities, respectively, $y$ and $z$ being the northward and upward coordinates, respectively, and "initial" and "final" refer to the initial and final sections used in any particular calculation.

We have discounted meridional advection as being important for the heat budget. On the northern boundary, the stream function based on the VM-ADCP (Fig. 1) indicates some inflow, but here the temperature gradients are generally weak (Figs. 2, 3, 4 and 5). On the southern boundary, the stream function (Fig. 1) indicates some inflow and outflow, but the hydrographic sections (Figs. 2, 3, 4 and 
5 ) indicate that the position of the front is very stable at $69^{\circ} \mathrm{S}$

The four sections across the westward-flowing current can be used in pairs so that starting at $3^{\circ} \mathrm{E}$, there are three final sections, $0^{\circ}, 3^{\circ} \mathrm{W}$ and $6^{\circ} \mathrm{W}$, starting at $0^{\circ}$ there are two final sections, $3^{\circ} \mathrm{W}$ and $6^{\circ} \mathrm{W}$, and starting at $3^{\circ} \mathrm{W}$ there is one final section, $6^{\circ} \mathrm{W}$. Thus, in all, there are six combinations of initial and final sections.
For each pair of sections and each density surface in the density range $27.60-27.90 \mathrm{~kg} \mathrm{~m}^{-3}$, with a spacing of $0.01 \mathrm{kgm}^{-3}$, the temperature change at each $0.5^{\circ}$ of latitude in the range $70^{\circ} \mathrm{S}$ and $60^{\circ} \mathrm{S}$ was calculated. The time for the observed temperature changes from section to section were obtained from the transit times calculated from the VM-ADCP data. The second differentials of the temperature at each $0.5^{\circ}$ latitude between 60 and $70^{\circ} \mathrm{S}$ from the initial and final sections were averaged together
Fig. $6 \theta \sigma_{\theta}$ diagrams for all four sections: Notice how the scatter reduces and the profiles from individual stations become closer to each other towards the west. a $3^{\circ} \mathrm{E}, \mathbf{b} 0^{\circ}, \mathbf{c} 3^{\circ} \mathrm{W}$, d $6^{\circ} \mathrm{W}$. The latitude is given by the colour of the profile according to the colour scale

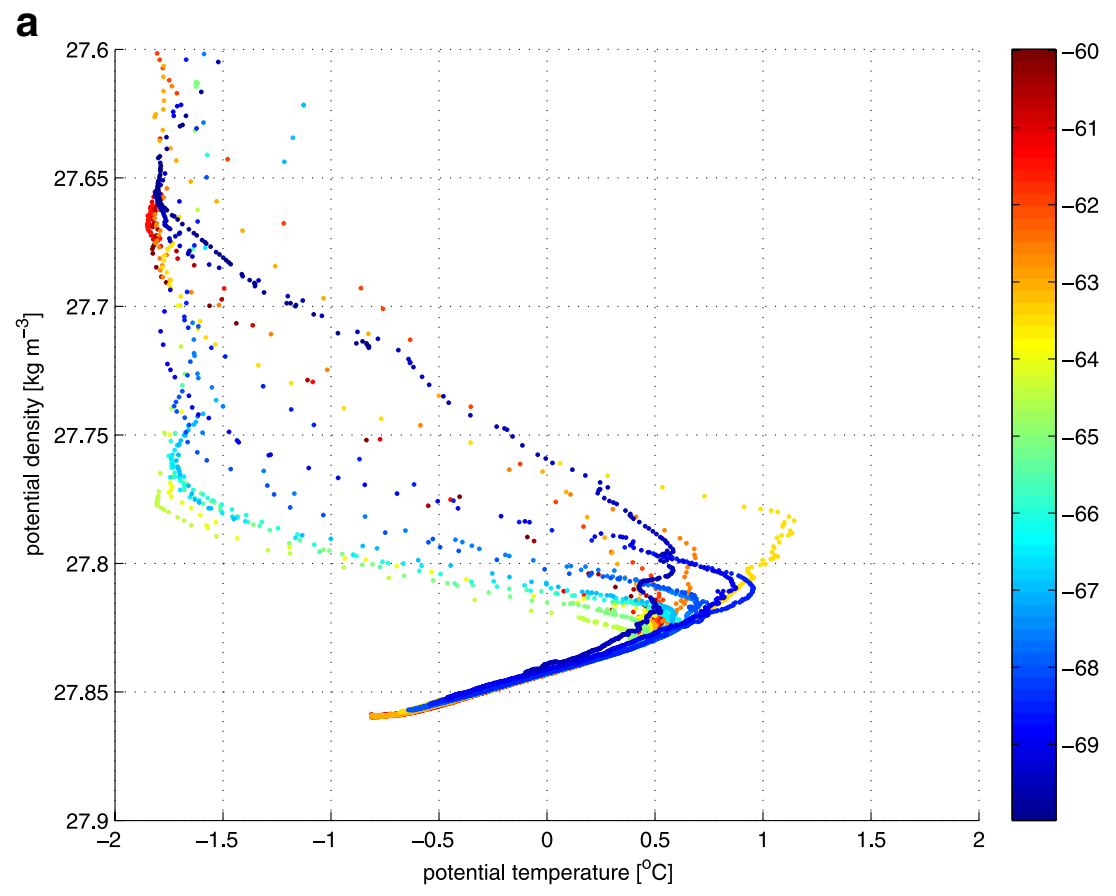

b

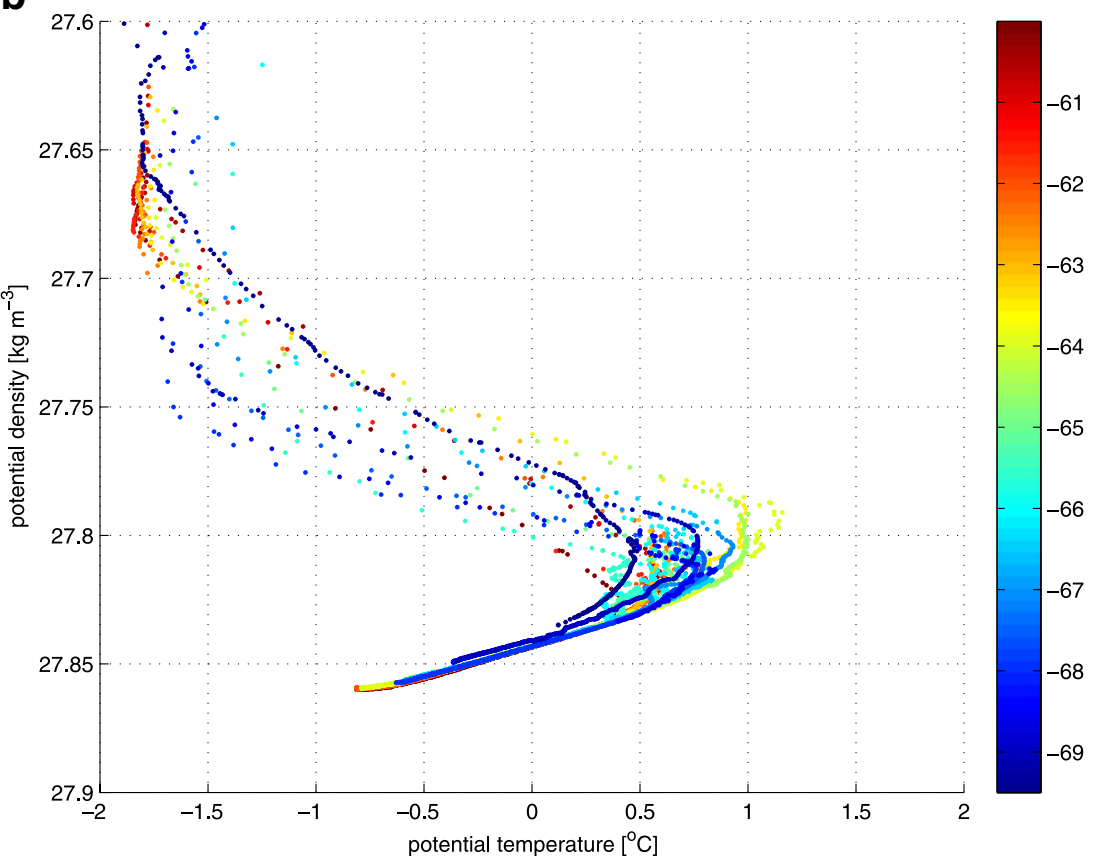


Fig. 6 (continued)
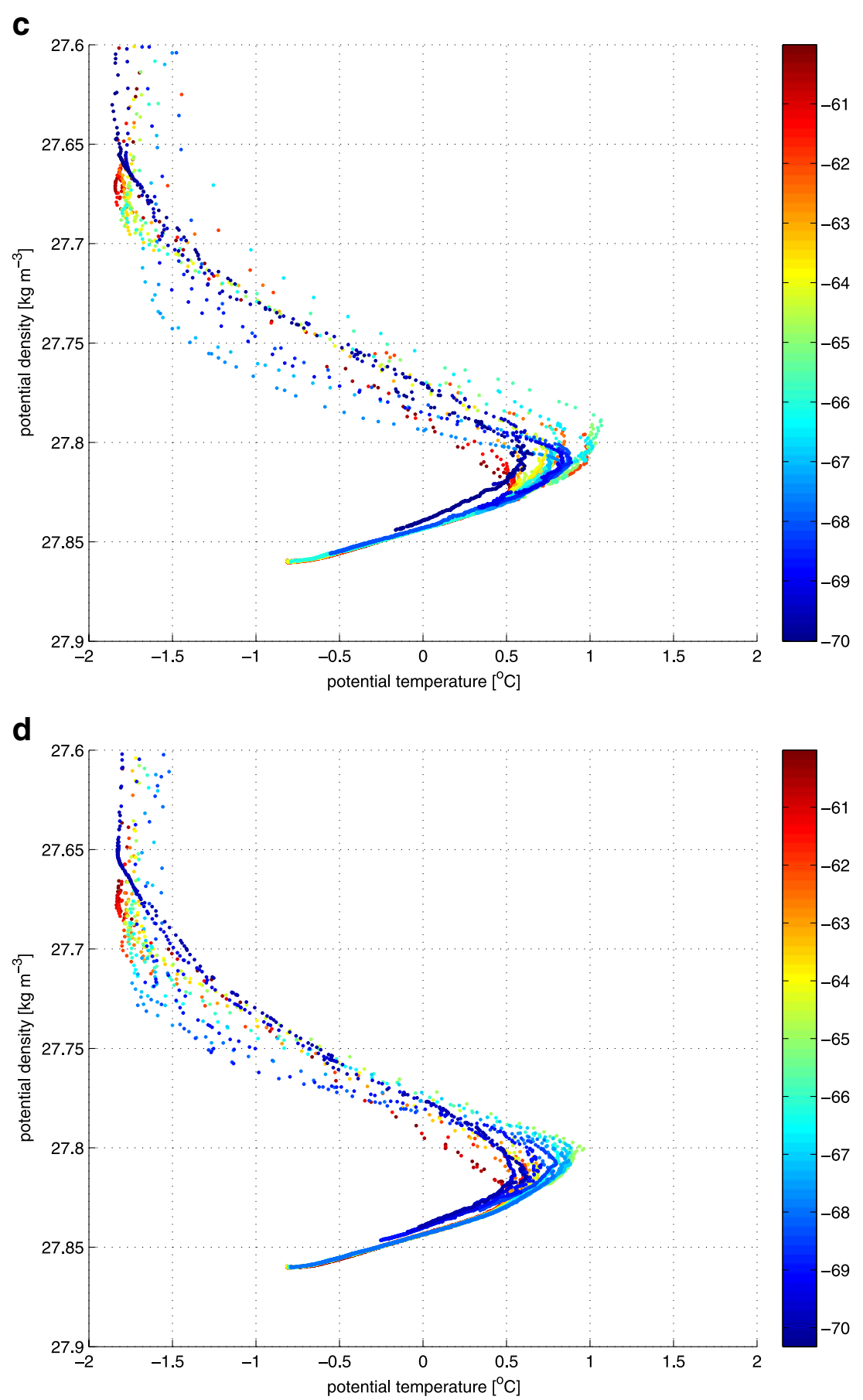

and then a multiple regression over the 21 points using the spatial curvatures as independent variables and the time rate of change of temperature as the dependent variable was conducted to find the coefficients $K_{\mathrm{h}}$ and $K_{\mathrm{v}}$. Thus, for each section pair and density surface, a value of each coefficient was inferred. Finally, the six values from the six section pairs were averaged together to obtain a profile of each coefficient as a function of density.

\subsection{Results}

The results of the multiple regression to find the mean profiles of eddy diffusivities are shown in Fig. 9. The horizontal diffusivity, $K_{\mathrm{h}}$, is shown in Fig. 9a; it can be seen that in the density range $27.68-27.76 \mathrm{kgm}^{-3}$, it has a value of about $70 \mathrm{~m}^{2} \mathrm{~s}^{-1}$ and in the range 27.77-27.82 $\mathrm{kgm}^{-3}$, which corresponds to the core of the Warm Deep Water, it has a value of about $140 \mathrm{~m}^{2} \mathrm{~s}^{-1}$. The continuous lines are the 
Fig. 7 Standard deviation of potential temperature, $\theta$, as a function of potential density, $\sigma_{\theta}$, showing the decrease in standard deviation from section to section proceeding from east to west, with maxima of about $0.82,0.48,0.34$ and $0.24 \mathrm{~K}$ for each of the each of the sections from east to west, respectively

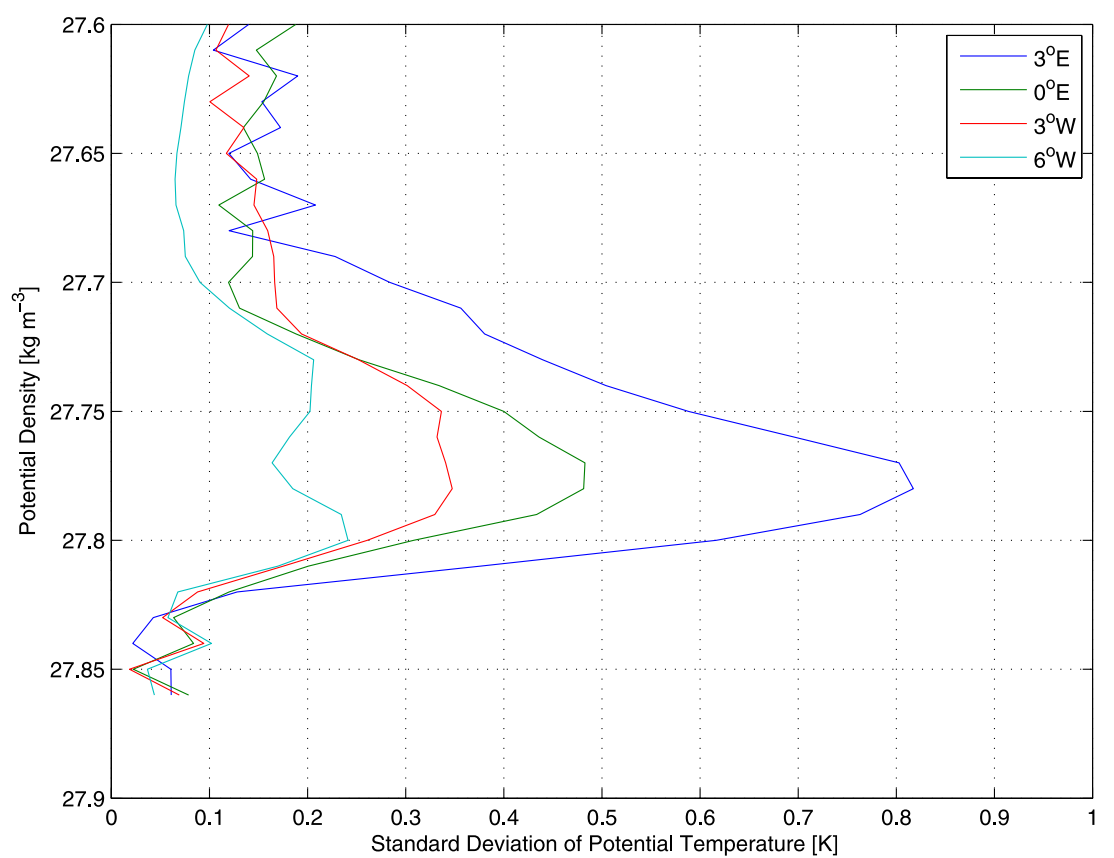

averages over the six combinations of initial and final sections and the dashed lines are these lines plus or minus their standard errors. Figure $9 \mathrm{~b}$ shows the correlation of the time rate of change and horizontal curvature terms as a function of depth; the depth averaged value of about 0.4 with 21 contributions is significant at the 90\% level.

The vertical diffusivity, $K_{\mathrm{v}}$, is shown in Fig. 9c, and it appears that it is only positively significantly different from zero in the range $27.76-27.81 \mathrm{kgm}^{-3}$. There, it has a typical value of about $2-3 \times 10^{-6} \mathrm{~m}^{2} \mathrm{~s}^{-1}$. The correlation between the time rate of change and the vertical curvature as a function of depth is shown in Fig. 9d; the peak value of 0.3 at $27.76 \mathrm{kgm}^{-3}$ is at best significant at the $80 \%$ level.

Because of concerns about processes associated with Maud Rise affecting the results of the calculations, they were repeated leaving out the section at $3^{\circ} \mathrm{E}$, east of the Rise, This halves the number of combinations of pairs of sections available for the calculation and so reduces the
Fig. 8 The heat content for the layer $150-1,000 \mathrm{~m}$ for each of the four sections with confidence limits showing that there is no significant change in heat content from one section to another for water below the surface layer. The confidence limits are based on assuming that each station represents an independent sample of water within the section

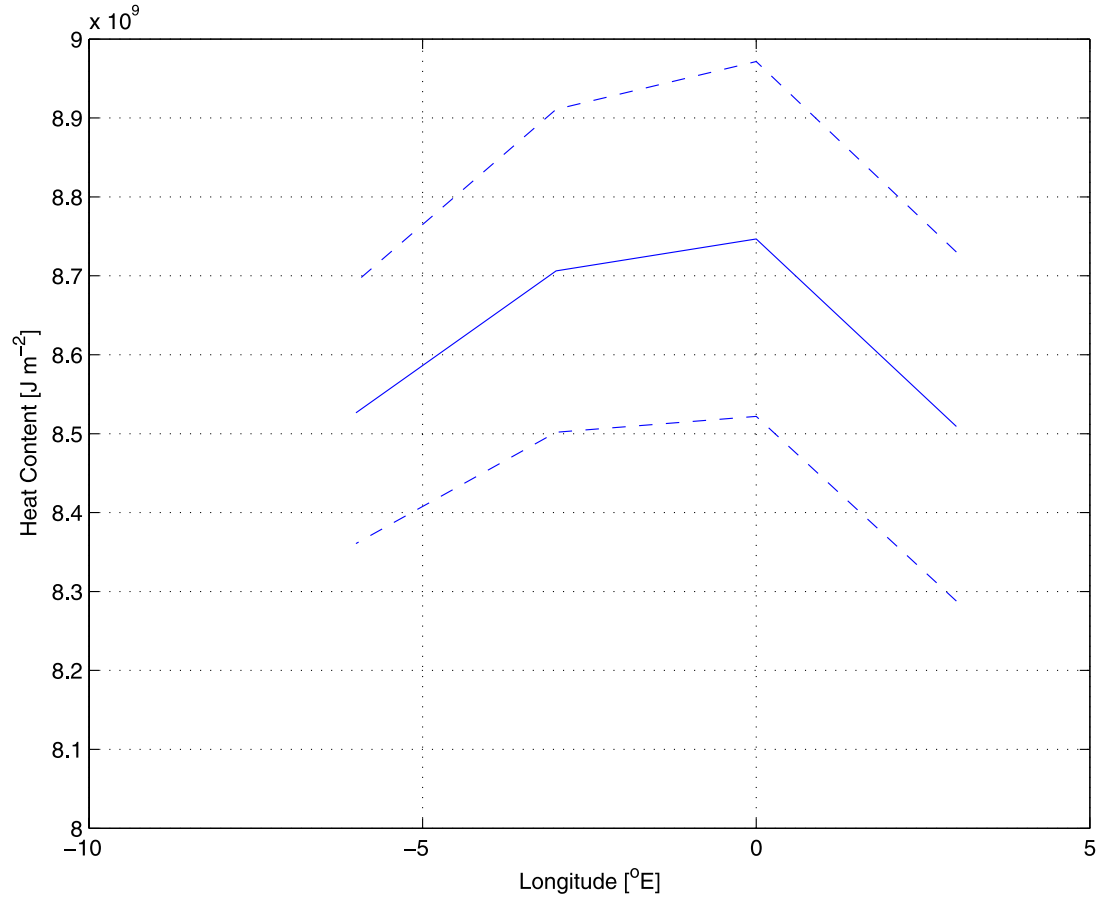


Table 2 Heat content and heat content change for the depth range 150-1,000 m

\begin{tabular}{|c|c|c|c|c|c|c|}
\hline Longitude & $\begin{array}{l}\text { Heat content } \\
\left(\mathrm{GJm}^{-2}\right)\end{array}$ & $\begin{array}{l}\text { Confidence limits for } \\
\text { heat content }\left(\mathrm{GJm}^{-2}\right)\end{array}$ & $\begin{array}{l}\text { Change in heat } \\
\text { content }\left(\mathrm{GJm}^{-2}\right)\end{array}$ & $\begin{array}{l}\text { Equivalent average } \\
\text { heat flux }\left(\mathrm{Wm}^{-2}\right)\end{array}$ & $\begin{array}{l}\text { Mean temperature } \\
\text { change }(\mathrm{K})\end{array}$ & $\begin{array}{l}\text { Mean surface layer } \\
\text { thickness change }(\mathrm{m})\end{array}$ \\
\hline $3^{\circ} \mathrm{E}$ & 8.51 & 0.22 & & & & \\
\hline $0^{\circ}$ & 8.75 & 0.23 & 0.24 & 40.48 & 0.07 & -19.27 \\
\hline $3^{\circ} \mathrm{W}$ & 8.71 & 0.21 & 0.04 & -6.88 & -0.01 & 3.28 \\
\hline $6^{\circ} \mathrm{W}$ & 8.53 & 0.17 & -0.18 & -30.64 & -0.05 & 14.59 \\
\hline Sum & & & -0.02 & 0.99 & 0.01 & -1.41 \\
\hline
\end{tabular}

Equivalent average heat flux assumes a time step of 68.0 days between sections

statistical significance of the results. They are, however, (Fig. 10) very similar to the results obtained using all four sections with values for $K_{\mathrm{h}}$ in the range $70-200 \mathrm{~m}^{2} \mathrm{~s}^{-1}$ and $K_{\mathrm{v}}$ if anything smaller at $\sim 1 \times 10^{-6} \mathrm{~m}^{2} \mathrm{~s}^{-1}$.

Using only the last pair of sections, 3 and $6^{\circ} \mathrm{W}$, which consider water well away from Maud Rise also leads to results similar to the calculations using more sections; in this case, $K_{\mathrm{h}}$ is in the range $200-300 \mathrm{~m}^{2} \mathrm{~s}^{-1}$ (not shown).

\section{Discussion}

Okubo (1971) reviewed estimates of horizontal eddy diffusivities and found that they were scale-dependent, as did Ledwell et al. (1998) who estimated values of $2 \mathrm{~m}^{2} \mathrm{~s}^{-1}$ for scales of $1-10 \mathrm{~km}$ increasing to $1,000 \mathrm{~m}^{2} \mathrm{~s}^{-1}$ for scales of 30-300 km from the dispersal of a tracer. Visbeck et al. (1997) obtained a range of values from $300 \mathrm{~m}^{2} \mathrm{~s}^{-1}$ for convective chimneys up to $2,000 \mathrm{~m}^{2} \mathrm{~s}^{-1}$ for eddies in a wind-driven channel. Hibbert et al. (2009) found a maximum value of $30-100 \mathrm{~m}^{2} \mathrm{~s}^{-1}$ for scales of 10 's km within a cold core eddy, agreeing with McWilliam's (1985) estimate from meddies. Cunningham and Haine (1995) obtained a value of $950 \mathrm{~m}^{2} \mathrm{~s}^{-1}$ and a scale of $166 \mathrm{~km}$ for the core of the Labrador Sea Water in the North Atlantic.

In view of this scale dependency, the values obtained for the horizontal diffusivity by our study, $70-140 \mathrm{~m}^{2} \mathrm{~s}^{-1}$, are reasonable for mesoscale eddies, if a little on the low side; our station spacing of $55 \mathrm{~km}$ only just captures the mesoscale features (Figs. 2, 3, 4 and 5) so that the estimates from our data might be expected to be the $\sim 10^{3} \mathrm{~m}^{2} \mathrm{~s}^{-1}$ appropriate to the larger $\sim 10^{2}$-km scales resolved. Interestingly, our area includes Maud Rise, which is considered as a region of enhanced eddy formation (as described in Section 1) and, hence, implicitly enhanced mixing. Our rather low values of horizontal diffusivity, however, suggest that the horizontal extent of the mixing effect of Maud Rise is limited, or that at least it was so when our measurements were made.

There is some indication that our value for $K_{\mathrm{h}}$ increases with depth and attains its maximum in the depth layer of the WDW; a number of theoretical papers over recent decades (Green 1970; Marshall 1981; Killworth 1997,
1998) have predicted that $K_{\mathrm{h}}$ should have a maximum at mid-depth. This prediction is based on the idea that if the eddy transport of potential vorticity $q$ can be parameterised by a diffusion term

$\overline{v^{\prime} q^{\prime}}=K_{h} \frac{\partial \bar{q}}{\partial y}$

and if the eddy transport is well behaved at all depths, then $K_{\mathrm{h}}$ must be large at the depth where the mean potential vorticity gradient reverses, this reversal being a necessary condition for baroclinic instability. More recently, Smith and Marshall (2009) have calculated the critical layer depth for the Southern Ocean, the depth at which theory predicts $K_{\mathrm{h}}$ should reach a maximum, and in our region, it appears to be in the range 500-1,500 m. In an earlier paper, Smith (2007) presented parameters related to baroclinic instability for the world's oceans, and these show that in our region, it is likely that the instability will only be weak; this might also explain why horizontal eddy diffusivity in our region appears slightly weaker than values obtained elsewhere for similar horizontal scales.

The values obtained for the vertical diffusivity are very low by global standards. Other workers (Polzin et al. 1997; Ledwell et al. 1998, 2000) have found values of order $1 \times$ $10^{-5} \mathrm{~m}^{2} \mathrm{~s}^{-1}$ in the relatively quiescent deep ocean. However, above rough topography in the Brazil Basin, Ledwell et al. (2000) obtained values of about $3 \times 10^{-4} \mathrm{~m}^{2} \mathrm{~s}^{-1}$. In the Nordic Seas, Naveira Garabato et al. (2004a) found values ranging from $3 \times 10^{-4} \mathrm{~m}^{2} \mathrm{~s}^{-1}$ right up to about $1 \times$ $10^{-2} \mathrm{~m}^{2} \mathrm{~s}^{-1}$; in deep water, the cause seemed to be breaking internal waves set off by flows over the topography, whilst in shallow water, downward propagating energy indicated a surface source for the internal wave energy, presumably ultimately the wind. Similar results were obtained for the Scotia Sea (Naveira Garabato et al. 2004b, 2007). Cisewski et al. $(2005,2008)$ obtained values of about $7 \times 10^{-4} \mathrm{~m}^{2} \mathrm{~s}^{-1}$ in the upper pycnocline of the ACC at about $20^{\circ} \mathrm{E}$, whilst Hibbert et al. (2009) found a maximum value of $3 \times 10^{-4} \mathrm{~m}^{2} \mathrm{~s}^{-1}$ within a cold core eddy, again agreeing reasonably well with McWilliam's (1985) estimate from meddies. However, very small rates of vertical mixing, $2-3 \times 10^{-6} \mathrm{~m}^{2} \mathrm{~s}^{-1}$, have been reported from the Arctic Ocean (Killworth and Smith 1984; Wallace et al. 1987; D'Asaro and Morison 1992; Rainville and 
Winsor 2008; Lenn et al. 2009). This could be understandable if it is considered that vertical mixing in the upper thermocline is in practice the intermittent breaking of internal waves; low internal wave energy was reported from the Arctic (D'Asaro and Morehead 1991). In the upper ocean, these waves are caused by the wind, but if the ocean is ice-covered, or possibly capped by a very stable surface melt water layer, then the ability of the wind to set off internal waves will be reduced. Our measurements were made in late spring and early summer as the seasonal sea ice was melting so that the water we observed had been ice covered until recently and thus protected from the wind.

If our estimate of the mean flow speed were too small, then this would also lead to small values of the eddy diffusivities. However, our average speed of $2.4 \mathrm{~cm} \mathrm{~s}^{-1}$ compares reasonably well with other published values. Calculating a latitudinally weighted mean flow for the southern limb of the Weddell Gyre from the top current meters of Klatt et al. (2005), average depth
Fig. 9 Eddy diffusivities and correlation coefficients as a function of density: a Horizontal diffusivity $K_{\mathrm{h}}$, which increases from about $70 \mathrm{~m}^{2} \mathrm{~s}^{-1}$ at the shallowest depths with significant values to a maximum of about $140 \mathrm{~m}^{2} \mathrm{~s}^{-1}$ at $27.78 \mathrm{~kg}$ $\mathrm{m}^{-3}$ in the WDW core. $\mathbf{b}$ Correlation between $\mathrm{d} \theta / \mathrm{d} t$ and $\partial^{2} \theta / \partial y^{2}$, which, with a typical value of about 0.4 for 21 contributions, is significant at the $90 \%$ level. c Vertical diffusivity $K_{\mathrm{v}}$, which only seems to show non-zero values of about $2-3 \times 10^{-6} \mathrm{~m}^{2} \mathrm{~s}^{-1}$ around the WDW core in the depth range $27.76-27.81 \mathrm{kgm}^{-3}$. d Correlation between $\mathrm{d} \theta / \mathrm{d} t$ and $\partial^{2} \theta / \partial z^{2}$ which has a maximum of 0.3 at $27.76 \mathrm{kgm}^{-3}$, which, for 21 contributions, is significant at the $80 \%$ level. The continuous lines are the averages over the six combinations of initial and final sections and the dashed lines are these lines plus or minus their standard errors

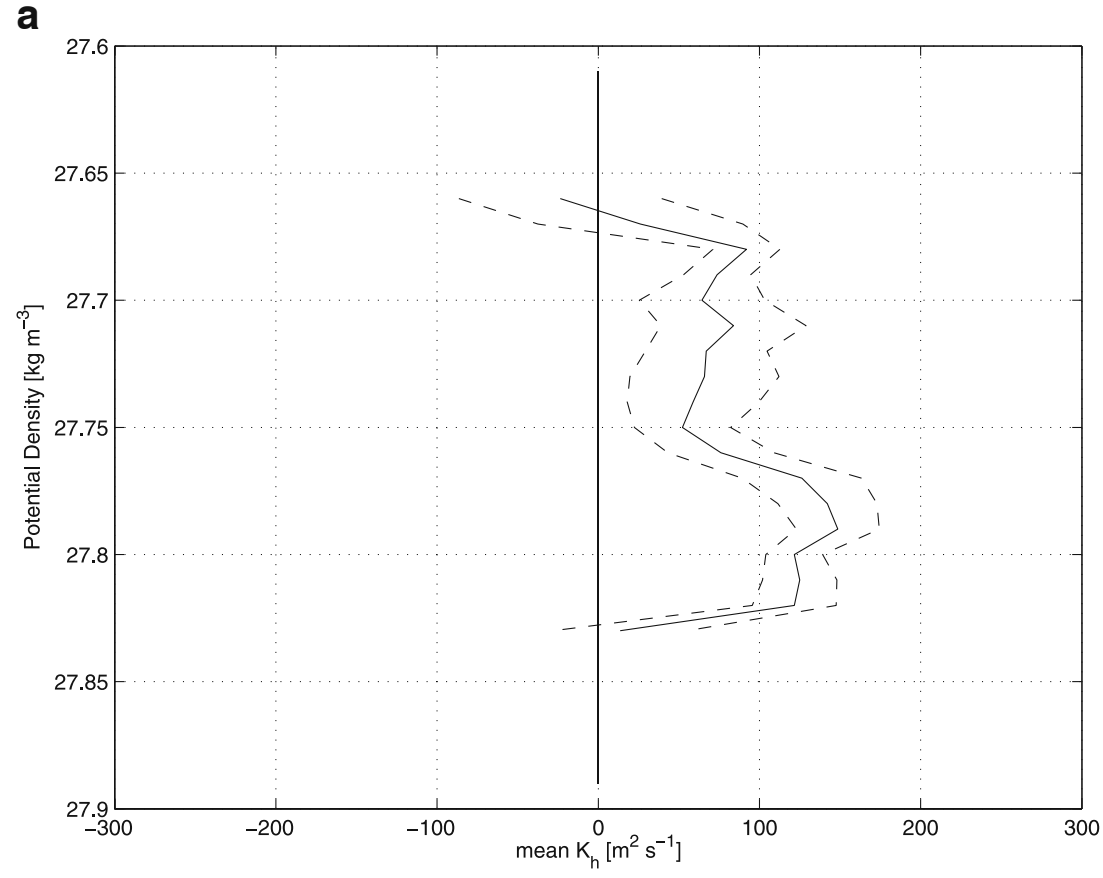

b

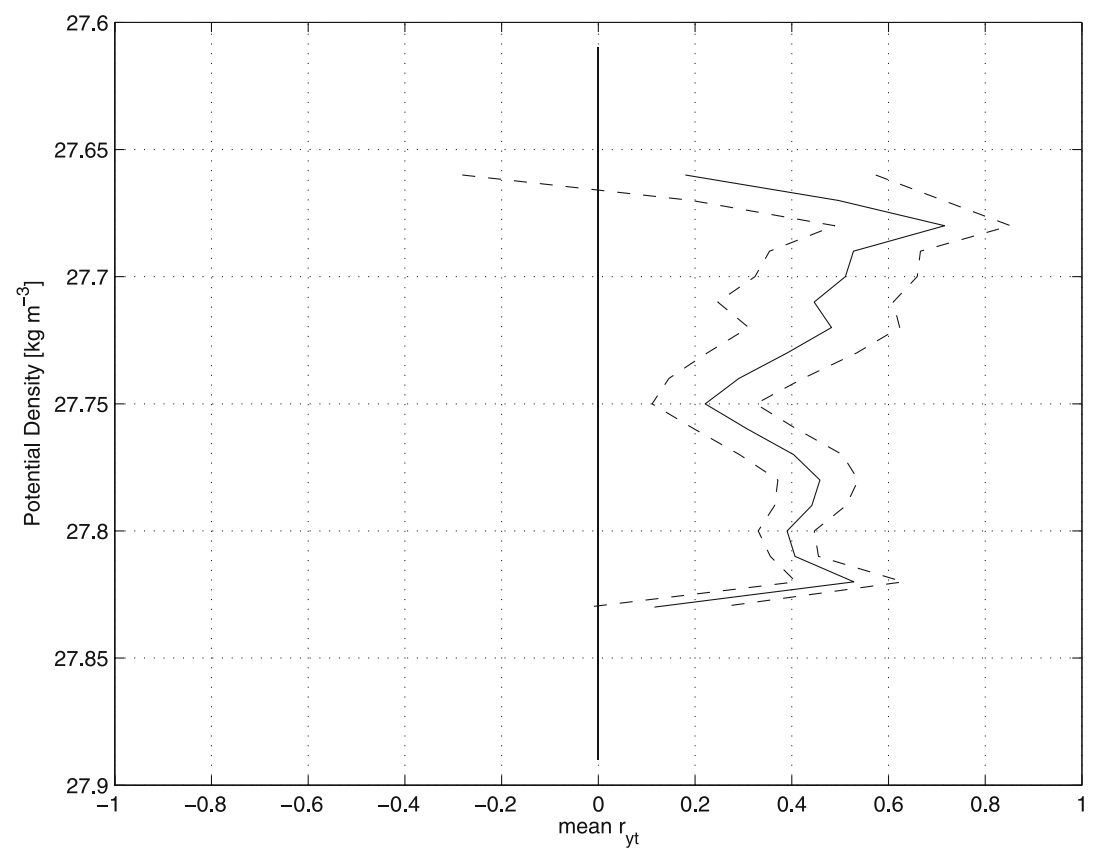


Fig. 9 (continued)

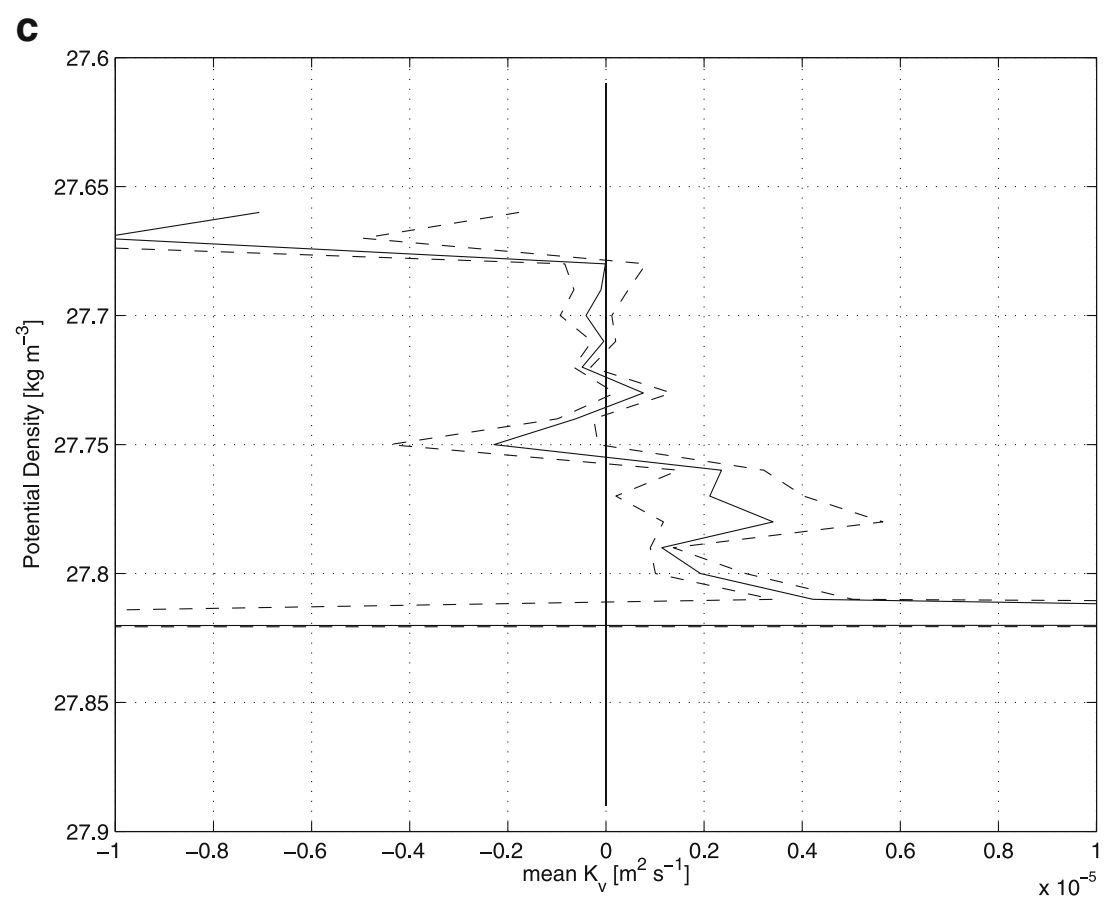

d

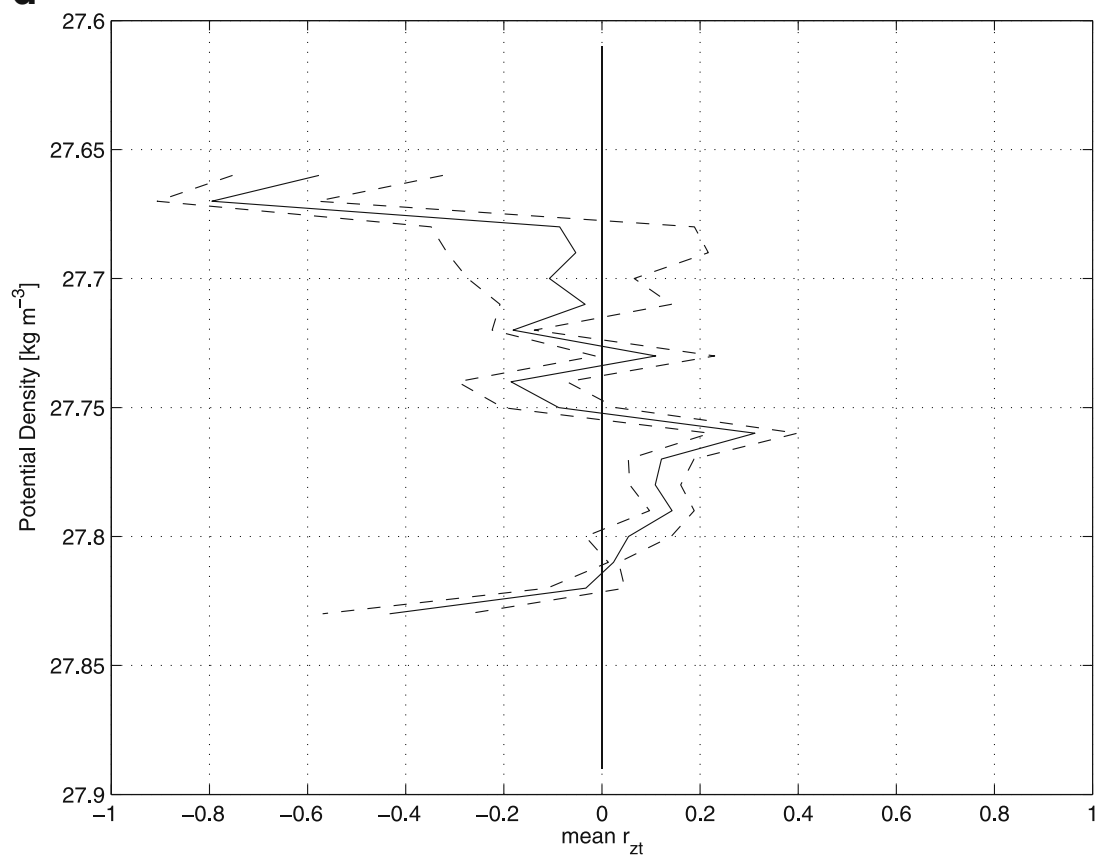

$210 \mathrm{~m}$, gives a westward flow of $1.5 \pm 0.2 \mathrm{cms}^{-1}$, and Muench et al. (2001) suggest that there is a consensus from observations and models for a near surface westward flow in this region of $2-3 \mathrm{cms}^{-1}$. Thus, it seems likely that our measurement of the mean flow speed is reliable and not too small.

The density surface $27.80 \mathrm{kgm}^{-3}$ has a mean depth of $227 \mathrm{~m}$ and is so still within the VM-ADCP depth range. The remaining deeper surfaces for which significant solutions for the mixing coefficients could be found were 27.81 and $27.82 \mathrm{kgm}^{-3}$, and these had average depths of 285 and $406 \mathrm{~m}$, respectively, so just below the VM-ADCP range. If at these depths the speed were slower than the average value we used, then the value of the mixing coefficients found would be lower.

The relative importance of horizontal and vertical diffusion can be estimated using scale analysis. Taking $K_{\mathrm{h}}$ and $K_{\mathrm{v}}$ to be 140 and $3 \times 10^{-6} \mathrm{~m}^{2} \mathrm{~s}^{-1}$, respectively, $\Delta \theta=$ 
$0.3 \mathrm{~K}$ and the horizontal and vertical scales, $L$ and $H$, to be $100 \mathrm{~km}$ and $200 \mathrm{~m}$, we can calculate that

horizontal diffusion $\sim K_{h} \Delta \theta / L^{2} \sim 4 \times 10^{-9} \mathrm{Ks}^{-1}$,

vertical diffusion $\sim K_{\mathrm{V}} \Delta \theta / H^{2} \sim 2 \times 10^{-11} \mathrm{Ks}^{-1}$.

Thus it can be seen that in our overall approximation, the horizontal diffusion outweighs the vertical by about two orders of magnitude. The choices of values for the parameters were made by looking at the hydrographic sections (Figs. 2, 3, 4 and 5). The temperature scale appears in both expressions and so does not affect their relative sizes. The horizontal scale is based on the size of the cores of warm water; in the westernmost section (Fig. 5), the scale might arguably be larger. The vertical scale for the cores is more arbitrary; indeed, if a greater scale were chosen, then the vertical diffusion would be even smaller. The relative importance of vertical and horizontal mixing has also been discussed by Lenn et al. (2009) for the case of the warm and saline Atlantic Water in the Arctic, and they
Fig. 10 As Fig. 9, but using data from only the sections at $0^{\circ}, 3^{\circ} \mathrm{W}$ and $6^{\circ} \mathrm{W}$

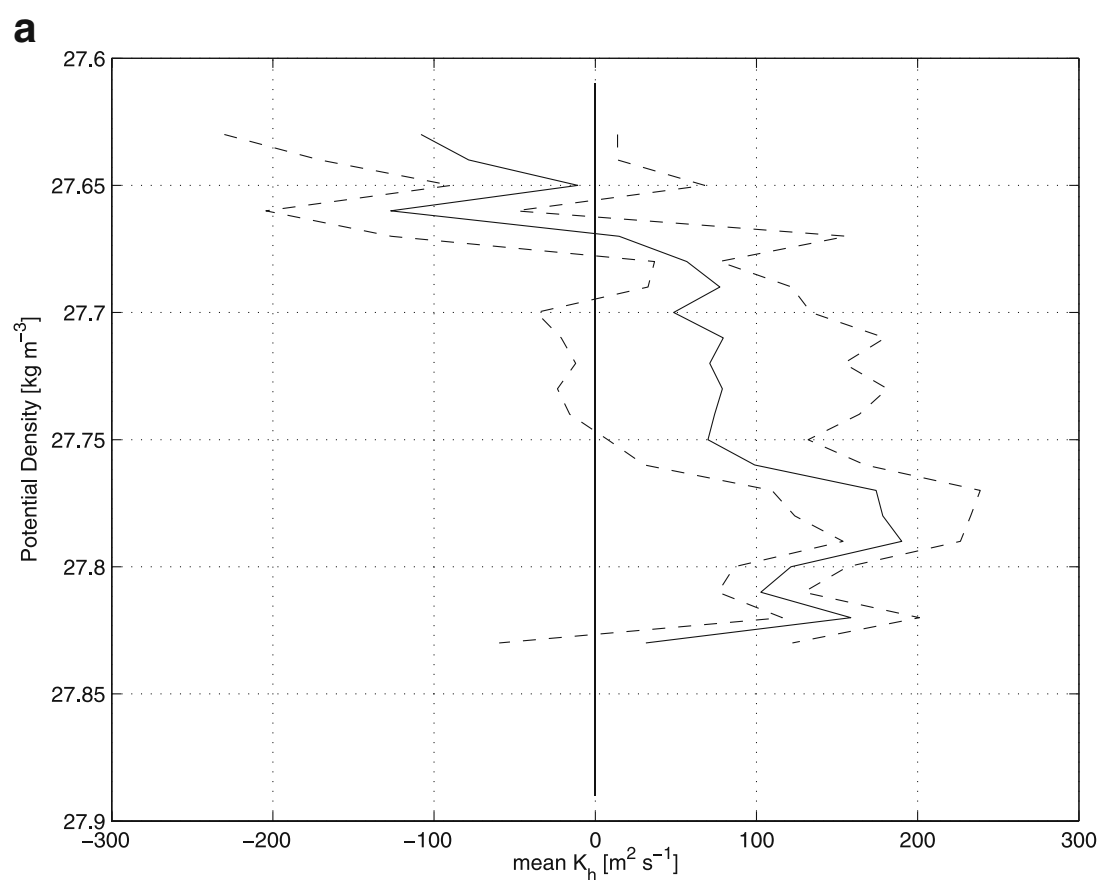

b

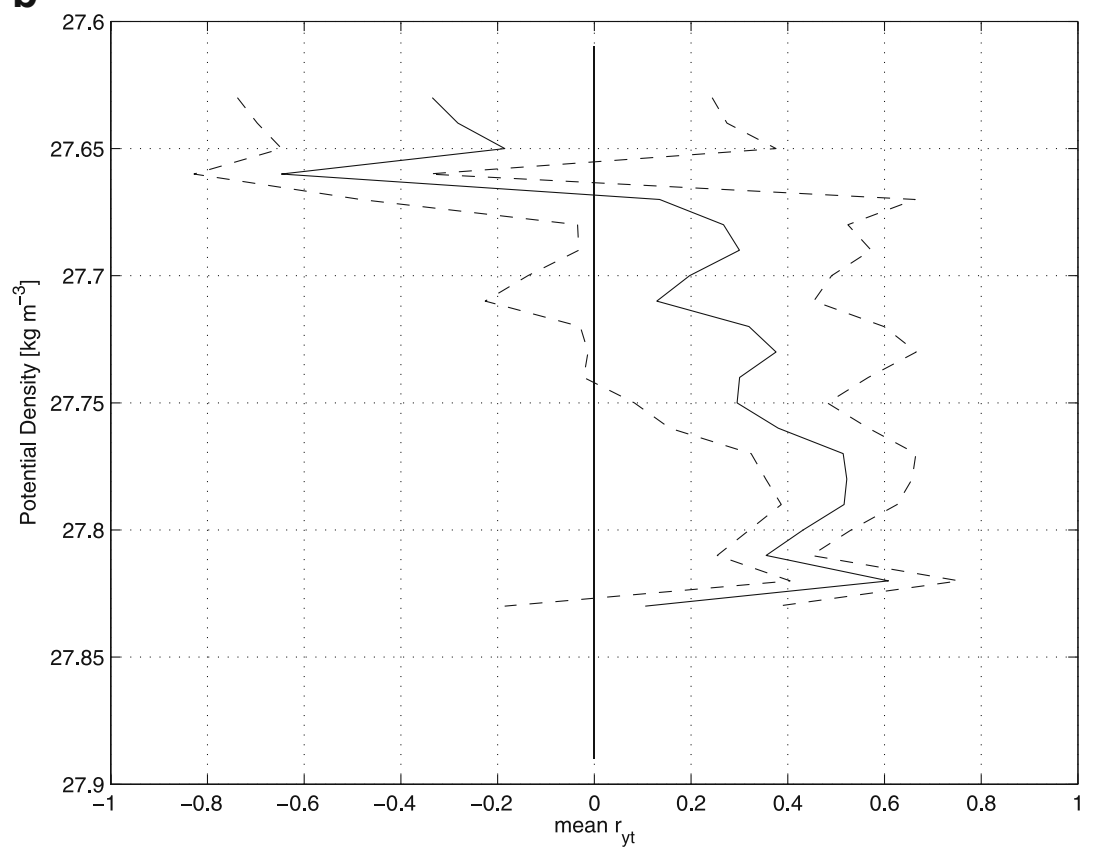


Fig. 10 (continued)
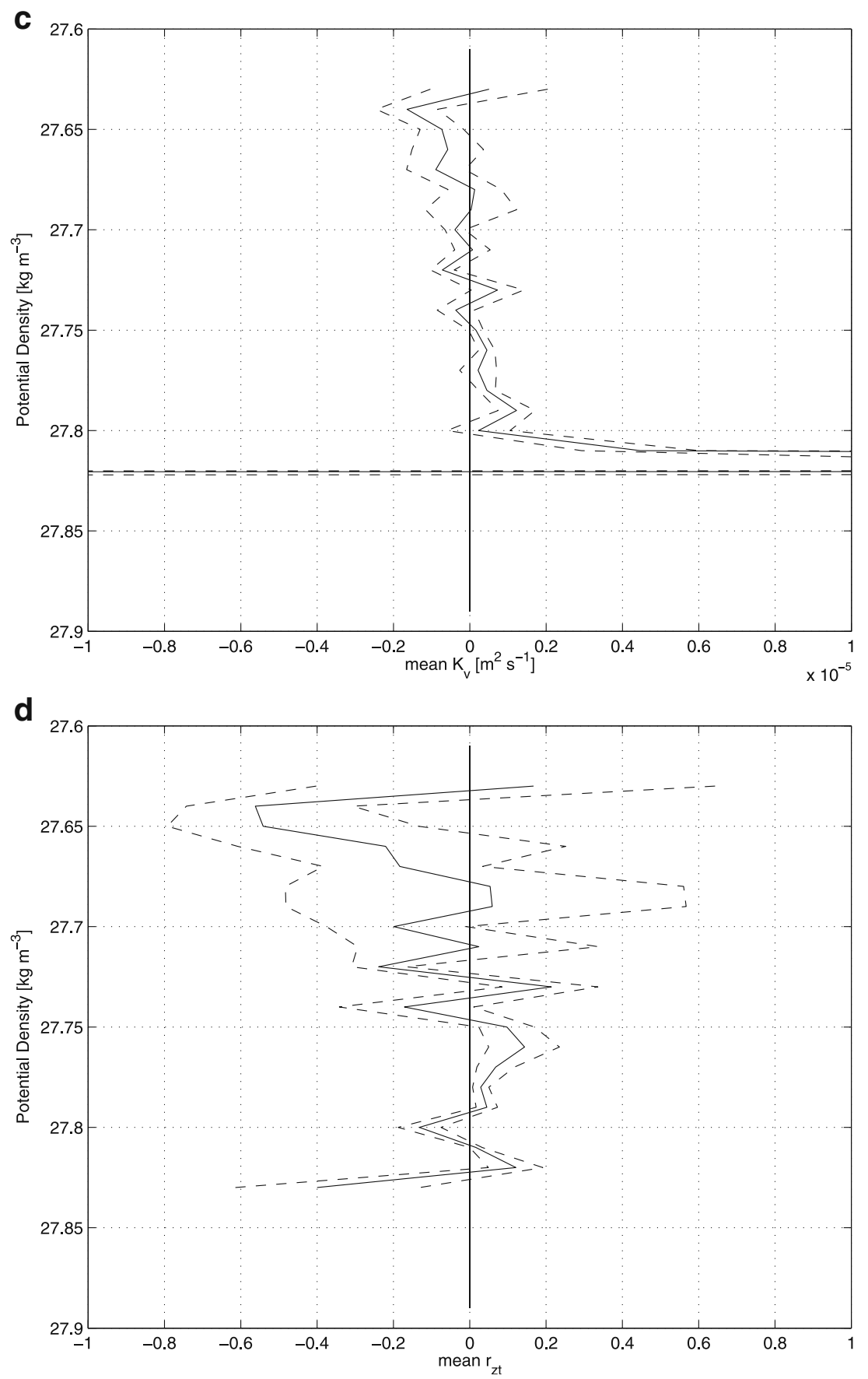

also concluded that horizontal mixing was more important than vertical mixing by an order of magnitude.

\section{Conclusions}

Our results are based on a synoptic snapshot and as such may not be representative of conditions all the time. However, for mixing in the pycnocline, we obtain above the WDW core $K_{\mathrm{h}} \sim 70 \mathrm{~m}^{2} \mathrm{~s}^{-1}$ and in the WDW core $K_{\mathrm{h}} \sim 140 \mathrm{~m}^{2} \mathrm{~s}^{-1}$. Above the WDW core, $K_{\mathrm{v}}$ is not distinguishable from zero, but in the WDW core, $K_{\mathrm{v}} \sim 3 \times$ $10^{-6} \mathrm{~m}^{2} \mathrm{~s}^{-1}$. Whilst, intuitively, the relatively warm and salty WDW must be losing heat and salt due to the presence of colder, fresher water above and below, it seems that the immediate mechanism for mixing of this water mass is lateral isopycnic mixing rather than vertical diapycnic mixing. A scale analysis suggests that horizontal mixing terms are likely to be bigger than vertical mixing terms. 
Acknowledgements We gratefully acknowledge the help and support of the captain and crew of Polarstern and our fellow scientists on board. HL's participation in the cruise was supported by a travel grant from the Royal Society. The Bundesministerium für Bildung und Forschung LAKRIS programme provided salary and travel for BC in a project led by Prof. M. Rhein at the Institute for Environmental Physics at the University of Bremen (Grant Reference LAKRIS 03F0400B).

\section{References}

Akimoto K (2006) Thermobaric deep convection, baroclinic instability, and their roles in vertical heat transport around Maud Rise in the Weddell Sea. J Geophys Res 111:C09027, 10 pp. doi:10.1029/ 2005JC003284

Bagriantsev NV, Gordon AL, Huber BA (1989) Weddell Gyre: temperature maximum stratum. J Geophys Res 94:8331-8334

Beckmann A, Hellmer HH, Timmermann R (1999) A numerical model of the Weddell Sea: large-scale circulation and water mass distribution. J Geophys Res 104:23375-23391

Beckmann A, Timmermann R, Pereira AF, Mohn C (2001) The effect of flow at Maud Rise on the sea-ice cover-numerical experiments. Ocean Dyn 52:11-25

Bersch M, Becker GA, Frey H, Koltermann KP (1992) Topographic effects of the Maud Rise on the stratification and circulation of the Weddell Gyre. Deep-Sea Res 39:303-331

Brennecke W (1921) Die ozeanographischen Arbeiten der Deutschen Antarktischen expedition 1911-1912. Aus Arch Dtsch Seewetterwarte 39:216

Carmack EC (1974) A quantitative characterisation of water masses in the Weddell Sea during summer. Deep-Sea Res 21:431-443

Cisewski B, Strass VH, Prandke H (2005) Upper-ocean vertical mixing in the Antarctic polar front zone. Deep Sea Res II 52:1087-1108. doi:10.1016/j.dsr2.2005.01.010

Cisewski B, Strass VH, Losch M, Prandke H (2008) Mixed layer analysis of a mesoscale eddy in the Antarctic Polar Front Zone. J Geophys Res 113:C05017. doi:10.1029/2007JC004372

Comiso JC, Gordon AL (1987) Recurring polynyas over the Cosmonaut Sea and the Maud Rise. J Geophys Res 92:2819-2833

Cunningham SA, Haine TWN (1995) Labrador Sea Water in the Eastern North Atlantic. Part II: mixing dynamics and the advective-diffusive balance. J Phys Oceanogr 25:666-678

D'Asaro EA, Morehead MD (1991) Internal waves and velocity fine structure in the Arctic Ocean. J Geophys Res 96:12725-12738

D'Asaro EA, Morison JH (1992) Internal waves and mixing in the Arctic Ocean. Deep-Sea Res 39(Suppl 2):S459-S484

Deacon GER (1933) A general account of the hydrology of the South Atlantic Ocean. Discov Rep VII:171-238

Deacon GER (1979) The Weddell Gyre. Deep-Sea Res 26A:981-995

de Steur L, Holland DM, Muench RD, McPhee MG (2007) The warm-water 'Halo' around Maud Rise: properties, dynamics and impact. Deep Sea Res I 54:871-896. doi:10.1016/j. dsr.2007.03.009

Fahrbach E, Rohardt G, Schröder M, Strass V (1994) Transport and structure of the Weddell Gyre. Ann Geophysicae 12:840-855

Fahrbach E, Hoppema M, Rohardt G, Schröder M, Wisotzki A (2004) Decadal-scale variations of water mass properties in the deep Weddell Sea. Ocean Dyn 54:77-91. doi:10.1007/s10236-003-0082-3

Fahrbach E, Hoppema M, Rohardt G, Schröder M, Wisotzki A (2006) Causes of deep-water variation: comment on the paper by L.H. Smedsrud 'Warming of the deep water in the Weddell Sea along the Greenwich Meridian: 1977-2001'. Deep Sea Res I 53:574577. doi:10.1016/j.dsr.2005.12.003
Gill AE (1973) Circulation and bottom water formation in the Weddell Sea. Deep-Sea Res 20:111-140

Gordon AL (1978) Deep Antarctic convection west of Maud Rise. J Phys Oceanogr 8:600-612

Gordon AL, Molinelli E, Baker T (1978) Large-scale relative dynamic topography of the Southern Ocean. J Geophys Res 83:30233032

Gouretski VV, Danilov AI (1993) Weddell Gyre: structure of the eastern boundary. Deep Sea Res I 40:561-582

Green JSA (1970) Transfer properties of the large-scale eddies and the general circulation of the atmosphere. Q J R Meteorol Soc 96:157-185

Hibbert A, Leach H, Strass V, Cisewski B (2009) Mixing in cyclonic eddies in the Antarctic circumpolar current. J Mar Res 67:1-23. doi: $10.1357 / 002224009788597935$

Holland DM (2001) Explaining the Weddell Polynya - a large ocean eddy shed at Maud Rise. Science 292:1697-1700

Iudicone D, Speich S, Madec G, Blanke B (2008) The global conveyor belt from a Southern Ocean perspective. J Phys Oceanogr 38:1401-1425

Killworth PD (1997) On the parameterization of eddy transfer. Part I: theory. J Mar Res 55:1171-1197

Killworth PD (1998) On the parameterization of eddy transfer. Part II: tests with a channel model. J Mar Res 56:349-374

Killworth PD, Smith JM (1984) A one-and-a-half dimensional model of the Arctic halocline. Deep-Sea Res 31:271-293

Klatt O, Fahrbach E, Hoppema M, Rohardt G (2005) The transport of the Weddell Gyre across the prime meridian. Deep Sea Res II 52:513-528. doi:10.1016/j.dsr2.2004.12.015

Ledwell JR, Watson AJ, Law CS (1998) Mixing of a tracer in the pycnocline. J Geophys Res 103:21499-21529

Ledwell JR, Montgomery ET, Polzin KL, St Laurent LC, Schmitt RW, Toole JM (2000) Evidence for enhanced mixing over rough topography in the abyssal ocean. Nature 403:179-182

Lenn YD, Wiles PJ, Torres-Valdes S, Abrahamsen EP, Rippeth TP, Simpson JH, Bacon S, Laxon SW, Polyakov I, Ivanov V, Kirillov S (2009) Vertical mixing at intermediate depths in the Arctic boundary current. Geophys Res Lett 36:L05601. doi:10.1029/ 2008GL036792

Lynn RJ, Reid JL (1968) Characteristics and circulation of deep and abyssal waters. Deep-Sea Res 15:577-598

Marshall JC (1981) On the parameterization of geostrophic eddies in the ocean. J Phys Oceanogr 11:257-271

McPhee MG, Ackley SF, Guest P, Huber BA, Martinson DG, Morison JH, Muench RD, Padman L, Stanton TP (1996) The Antarctic zone flux experiment. Bull Am Meteorol Soc 77:1221-1232

McPhee MG (2000) Marginal thermobaric stability in the ice-covered upper ocean over Maud Rise. J Phys Oceanogr 30:2710-2722

McPhee MG, Kottmeier C, Morison JH (1999) Ocean heat flux in the Central Weddell Sea during winter. J Phys Oceanogr 29:11661179

McWilliams JC (1985) Submesoscale, coherent vortices in the ocean. Rev Geophys 23:165-182

Mosby H (1934) The waters of the Atlantic Antarctic Ocean. Scientific results of the Norwegian Antarctic expeditions 19271928, instituted and financed by Consul Lars Christensen 1(11) Det Norske Videnskaps-Akademi i Oslo, p 131

Muench RD, Morison JH, Padman L, Martinson D, Schlosser P, Huber B, Hohmann R (2001) Maud Rise revisited. J Geophys Res 106:2424-2440

Naveira Garabato AC, Oliver KIC, Watson AJ and Messias M-J (2004a) Turbulent diapycnal mixing in the Nordic Seas. J Geophys Res 109:C12010, 9 pp. doi:10.1029/2004JC002411

Naveira Garabato AC, Polzin KL, King BA, Heywood KJ, Visbeck M (2004b) Widespread intense turbulent mixing in the Southern Ocean. Science 303:210-213. doi:10.1126/science.1090929 
Naveira Garabato AC, Stevens DP, Watson AJ, Roether W (2007) Short-circuiting of the overturning circulation in the Antarctic circumpolar current. Nature 447:194-197. doi:10.1038/ nature 05832

Okubo A (1971) Oceanic diffusion diagrams. Deep-Sea Res 18:789802

Orsi AH, Nowlin WD Jr, Whitworth T III (1993) On the circulation and stratification of the Weddell Gyre. Deep Sea Res I 40:169 203

Padman L, Fricker HA, Coleman R, Howard S, Erofeeva L (2002) A new tide model for the Antarctic ice shelves and seas. Ann Glaciol 34:247-254

Polzin KL, Toole JM, Ledwell JR, Schmitt RW (1997) Spatial variability of turbulent mixing in the Abyssal Ocean. Science 276:93-96

Rainville L, Winsor P (2008) Mixing across the Arctic Ocean: microstructure observations during the Beringia 2005 expedition. Geophys Res Lett 35:L08606. doi:10.1029/2008GL033532

Schröder M, Fahrbach E (1999) On the structure and transport of the eastern Weddell Gyre. Deep Sea Res II 46:501-527

Seabrooke JM, Hufford GL, Elder RB (1971) Formation of Antarctic Bottom Water in the Weddell Sea. J Geophys Res 76:2164-2178
Smedsrud LH (2005) Warming of the deep water in the Weddell Sea along the Greenwich Meridian: 1977-2001. Deep Sea Res I 52:241-258. doi:10.1016/j.dsr.2004.10.004

Smedsrud LH (2006) Causes of deep-water variations: reply to comment by E. Fahrbach, M. Hoppema, G. Rohardt, M. Schröder and A. Wisotzki. Deep Sea Res I 53:578-580. doi:10.1016.j. dsr.2005.12.010

Smith KS (2007) The geography of linear baroclinic instability in Earth's oceans. J Mar Res 65:655-683

Smith KS, Marshall JC (2009) Evidence for enhanced eddy mixing at middepth in the Southern Ocean. J Phys Oceanogr 39:50-69

Strass V (ed) (2007) The expedition ANTARKTIS-XXIII/2 of the research vessel "Polarstern" in 2005/2006. Berichte zur Polar-und Meeresforschung/Reports on Polar and Marine Research 568, p 138

Visbeck M, Marshall J, Haine T, Spall M (1997) Specification of eddy transfer coefficients in coarse-resolution ocean circulation models. J Phys Oceanogr 27:381-402. doi:1520-1997)027/1520-0485(1997) 027<0381:SOETCI $>2.0 . \mathrm{CO} ; 2$

Wallace DWR, Moore RM, Jones EP (1987) Ventilation of the Arctic Ocean cold halocline: rates of diapycnal and isopycnal transport, oxygen utilisation, and primary production inferred using chlorofluoromethane distributions. Deep-Sea Res 34:1957-1979 